Original Article

\title{
Characterization of toxin-producing strains of Dinophysis spp. (Dinophyceae) isolated from French coastal waters, with a particular focus on the $D$. acuminata-complex
}

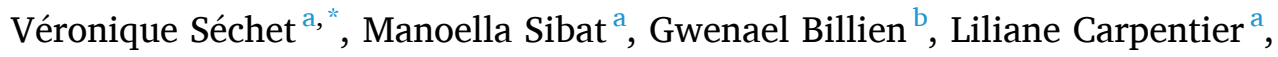 \\ Georges-Augustin Rovillon ${ }^{a}$, Virginie Raimbault ${ }^{a}$, Florent Malo ${ }^{a}$, Sylvain Gaillard ${ }^{\mathrm{a}}$, \\ Myriam Perrière-Rumebe ${ }^{c}$, Philipp Hess ${ }^{a}$, Nicolas Chomérat ${ }^{b}$ \\ ${ }^{a}$ Ifremer, DYNECO, Laboratoire Phycotoxines, F-44000 Nantes, France \\ ${ }^{\mathrm{b}}$ Ifremer, LITTORAL, Laboratoire Environnement Ressources de Bretagne Occidentale, Station de Biologie Marine de Concarneau, 29900 Concarneau, France \\ ${ }^{c}$ Ifremer, LITTORAL, Laboratoire Environnement Ressources, 33120 Arcachon, France
}

\section{A R T I C L E I N F O}

\section{Keywords:}

Dinophysis spp.

Phylogeny

Taxonomy

Toxin profiles

\begin{abstract}
A B S T R A C T
Dinoflagellates of the genus Dinophysis are the most prominent producers of Diarrhetic Shellfish Poisoning (DSP) toxins which have an impact on public health and on marine aquaculture worldwide. In particular, Dinophysis acuminata has been reported as the major DSP agent in Western Europe. Still, its contribution to DSP events in the regions of the English Channel and the Atlantic coast of France, and the role of the others species of the Dinophysis community in these areas are not as clear. In addition, species identification within the D. acuminata complex has proven difficult due to their highly similar morphological features. In the present study, 30 clonal strains of the dominant Dinophysis species have been isolated from French coasts including the English Channel (3 sites), the Atlantic Ocean (11 sites) and the Mediterranean Sea (6 sites). Morphologically, strains were identified as three species: $D$. acuta, $D$. caudata, $D$. tripos, as well as the $D$. acuminata-complex. Sequences of the ITS and LSU rDNA regions confirmed these identifications and revealed no genetic difference within the $D$. acuminata-complex. Using the mitochondrial gene cox 1 , two groups of strains differing by only one substitution were found in the D. acuminata-complex, but SEM analysis of various strains showed a large range of morphological variations. Based on geographical origin and morphology, strains of the subclade A were ascribed to ' $D$. acuminata' while those of the subclade B were ascribed to ' $D$. sacculus'. Nevertheless, the distinction into two separate species remains questionable and was not supported by our genetic data. The considerable variations observed in cultured strains suggest that physiological factors might influence cell contour and bias identification. Analyses of Dinophysis cultures from French coastal waters using liquid chromatography coupled to tandem mass spectrometry (LC-MS/MS) revealed species-conserved toxin profiles for D. acuta (dinophysistoxin 2 (DTX2), okadaic acid (OA), pectenotoxin 2 (PTX2)), D. caudata (PTX2) and D. tripos (PTX2), irrespective of geographical origin (Atlantic Ocean or Mediterranean Sea). Within the $D$. acuminata-complex, two different toxin profiles were observed: the strains of ' $D$. acuminata' (subclade A) from the English Channel and the Atlantic Ocean contained only OA while strains of ' $D$. sacculus' (subclade B) from Mediterranean Sea/Atlantic Ocean contained PTX2 as the dominant toxin, with OA and C9-esters also being present, albeit in lower proportions. The same difference in toxin profiles between ' $D$. sacculus' and ' $D$. acuminata' was reported in several studies from Galicia (NW- Spain). This difference in toxin profiles has consequences in terms of public health, and consequently for monitoring programs. While toxin profile could appear as a reliable feature separating ' $D$. acuminata' from ' $D$. sacculus' on both French and Spanish coasts, this does not seem consistent with observations on a broader geographical scale for the D. acuminata complex, possibly due to the frequent lack of genetic characterization.
\end{abstract}

\footnotetext{
* Corresponding author.

E-mail address: vsechet@ifremer.fr (V. Séchet).
} 


\section{Introduction}

Diarrhetic shellfish poisoning (DSP) events have been reported worldwide since the first documented occurrence in 1976 and 1977 along the coast of the Tohoku district in Japan which led to the identification of the dinoflagellate Dinophysis fortii as the toxin producer (Yasumoto et al., 1980). Dinophysis is one of the largest genera of dinoflagellates, with more than 200 species ascribed (Hallegraeff and Lucas, 1988), of which 133 are accepted taxonomically (Guiry, 2020). Only ten of these, as well as two species of the closely related genus Phalacroma, have been unambiguously reported to contain DSP toxins (MacKenzie et al., 2005; Reguera et al., 2012; Zingone and Larsen, 2020). A few hundred cells of toxic Dinophysis sp. per liter may suffice to generate diarrhetic intoxications in humans by consuming contaminated shellfish (Yasumoto et al., 1985). Dinophysis species are known to produce two groups of bioactive lipophilic compounds: okadaic acid (OA) and its derivatives the dinophysistoxins (DTXs) that inhibit phosphoprotein phosphatases, are polyethers containing a carboxylic acid functionality and cause diarrhetic effects, while pectenotoxins (PTXs) are a family of polyether-lactones that are much less toxic via the oral route and do not induce diarrhea (Miles et al., 2004a).

During June-July 1983, at least 3,300 people suffered symptoms of diarrhetic shellfish poisoning (DSP) after eating contaminated mussels (Mytilus edulis) from Southern Brittany (France) before a sanitary ban was enforced (Alzieu et al., 1983). This outbreak was associated with Dinophysis acuminata (Lassus et al., 1985). Following this toxic episode the National Phytoplankton and Phycotoxins Monitoring network (REPHY) was set up in 1984 (Belin et al., 2020). Okadaic acid was detected in contaminated mussels collected at le Havre (English Channel) during a bloom of $D$. acuminata in 1984, whereas DTXs or PTXs were under the limit of detection (Kumagai et al., 1986). The presence of OA in bivalve molluscs collected on the English channel and Atlantic coasts of France was confirmed over the following years but it was noted that shellfish toxicity was not always well correlated to planktonic cell concentrations (Marcaillou-Le Baut and Masselin, 1989). Until the end of the 1990s, little attention was paid to PTXs, considered then to be a toxin restricted to $D$. fortii proliferations in Japan (Reguera et al., 2014). In France, the presence of PTX2 and its derivatives was identified in shellfish by liquid chromatography (LC) coupled with mass spectrometry (MS) analysis for the first time in 2004 in Thau lagoon on the Mediterranean coast, and in 2005 in Arcachon Basin on the Atlantic coast (Amzil et al., 2007). Since then, high amounts of PTX2-seco-acid have been regularly reported in the Mediterranean lagoons at sites of shellfish aquaculture (Belin and Soudant, 2018).

On the French coastline, Dinophysis has the particularity of rarely proliferating at high concentrations but it can be observed on all three major coastlines, i.e. the English Channel, the Atlantic and Mediterranean coasts. Maximum annual concentrations are generally below 10,000 cells $\cdot \mathrm{L}^{-1}$, however, higher Dinophysis concentrations have been recorded on the Normandy coast in August 2016, i.e. a maximum of 803,000 cells $\cdot \mathrm{L}^{-1}$, which is the highest value ever reached for this taxon during 30 years of the REPHY monitoring program (Belin and Soudant, 2018). In the frame of this national monitoring program, D. acuminata and $D$. sacculus have been identified as the dominant species at the origin of toxic episodes in the Atlantic/English Channel regions and the Mediterranean Sea, respectively, with also the more episodic or localized presence of D. acuta, D. caudata, D. fortii and D. tripos (Belin and Soudant, 2018). Highest concentrations of Dinophysis acuminata usually appear in early spring in the bay of Arcachon, subsequently (late spring - early summer) in southern Brittany, and finally in August in Normandy (English Channel) where it can form blooms. D. sacculus is widely recorded in cold and temperate waters (Zingone et al., 1998), but concentrations over $1 \times 10^{3}$ cells $\cdot \mathrm{L}^{-1}$ of this species have been only reported in warm-temperate semi-enclosed coastal areas with freshwater inputs in southwestern Europe and the Mediterranean Sea (Reguera et al., 2014). It is the dominant species in French Mediterranean lagoons but it is also observed in important aquaculture sites in western France (Belin and Soudant, 2018). Nevertheless, morphological variability due to biogeographical intra-specific differences (Zingone et al., 1998) and life cycle polymorphism (Berland et al., 1995; Nézan, 2000) resulted in uncertainty in the morphological identification and quantification of Dinophysis spp. natural samples. Since the often co-occurring species $D$. acuminata, $D$. sacculus, $D$. ovum and $D$. pavillardii are difficult to discriminate by morphology, the term " $D$. acuminata complex" has been introduced (Bravo et al., 1995; Lassus and Bardouil, 1991). The investigation into the morphological variability of $D$. sacculus and $D$. acuminata conducted by Zingone et al. (1998) concluded that despite the morphological variation observed in $D$. sacculus in the Mediterranean sea and along the European Atlantic coast, it could be distinguished from Atlantic populations of $D$. acuminata by small details. For instance, the shape of hypothecal plates and curvature of the dorsal edge have been proposed to distinguish the more elongated and rectangular $D$. sacculus from the shorter and more convex D. acuminata. Moreover, in that study, the authors pointed out that toxic events in western France associated with $D$. sacculus need a further confirmation about the responsible species (Zingone et al., 1998).

Molecular methods have been successfully applied to identify many dinoflagellate species and clades (Penna and Magnani, 1999; Scholin and Anderson, 1996), but the genetic delineation of species within the D. acuminata-complex is unclear, making either ribosomal genes (SSU and LSU rDNA) or ITS regions (Edvardsen et al., 2003; Marin et al., 2001; Raho et al., 2008) almost uninformative (Wolny et al., 2020). To overcome this issue Raho et al. $(2008,2013)$ suggested that the mitochondrial gene of the cytochrome $c$ oxidase I $(\operatorname{cox} 1)$ may be more appropriate in distinguishing $D$. acuminata from $D$. ovum and $D$. sacculus.

Numerous field studies (Batifoulier et al., 2013; Berland et al., 1995; Delmas et al., 1993; Gentien et al., 1995; Lassus et al., 1988; Maestrini, 1998) and observations as part of the REPHY monitoring program have led to a better understanding of the biology, toxin-production and ecology of Dinophysis spp. on French coasts. Nonetheless, attempts to culture Dinophysis on autotrophic or mixotrophic modes (Maestrini et al., 1995) have failed until elucidation of the three-link food chain (cryptophyte-ciliate-dinoflagellate) and successful establishment of Dinophysis acuminata cultures (Park et al., 2006). Following this breakthrough discovery, several Dinophysis spp. have been maintained in culture, allowing combined studies of the morphology, genetics, ecophysiology and toxin profiles on the same strains.

The aim of this work was to characterize the genetic and morphological variability as well as the toxin profiles of the dominant species of Dinophysis isolated from French coastal waters, including the English Channel, the Bay of Biscay (Atlantic Ocean) and the Mediterranean Sea. A set of 30 monoclonal cultures including strains of the D. acuminatacomplex (putatively $D$. acuminata and $D$. sacculus), D. acuta, D. caudata and $D$. tripos have been isolated from different locations between 2015 and 2019.

\section{Material and methods}

\subsection{Sampling}

Plankton net-haul (10 $\mu \mathrm{m}$ mesh) and Niskin bottle samples were collected at twenty different sites in the English Channel, Atlantic and Mediterranean coastal waters and over several seasons from May 2015 to August 2019 (Fig. 1, Table 1). Dinophysis cells were isolated using a drawn glass micropipette under an inverted IM35 microscope (Carl Zeiss, Oberkochen, Germany), washed three times and transferred to a 4-well cell culture plate (Thermo Scientific ${ }^{\circledR}$, Waltham, United States).

\subsection{In vitro culturing of Dinophysis spp.}

Thirty monoclonal strains of Dinophysis (Table 1) were grown in diluted $\mathrm{K} / 2(-\mathrm{Si}) / \mathrm{L} 1 / 20$ (-Si) culture media (Guillard and Hargraves, 


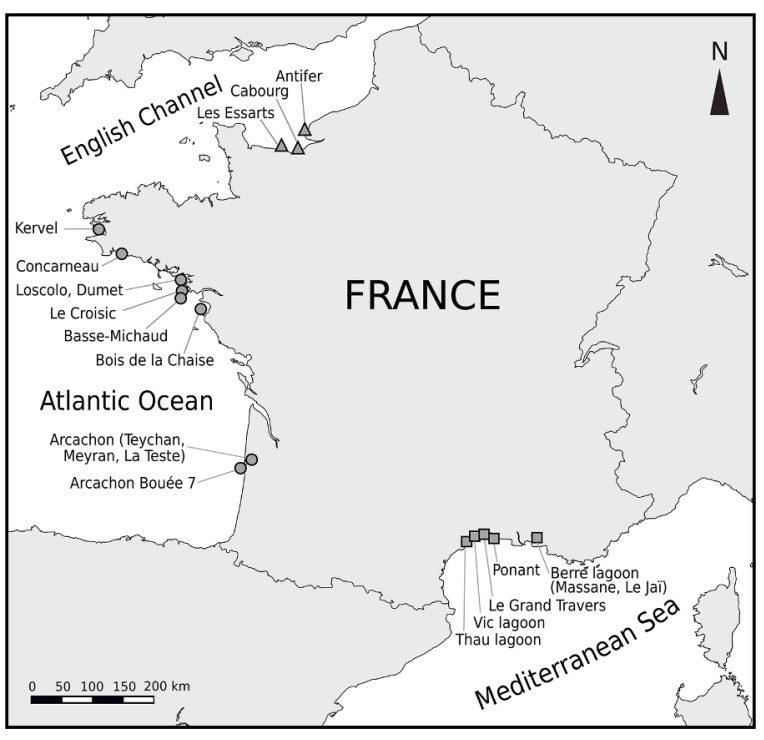

Fig. 1. Map showing the different sites where the strains have been isolated on French coasts (see Table 1).

1993) prepared with filtered seawater $\left(0.2 \mu \mathrm{m}\right.$ Steritop Corning ${ }^{\circledR}$, Corning, United States) at $\mathrm{pH} 8.2$ and a salinity of 35 . They were maintained in a thermo-regulated room at $17^{\circ} \mathrm{C}$ and provided $\sim 90$ $\mu \mathrm{mol} \mathrm{m} \mathrm{m}^{2} \mathrm{~s}^{-1}$ PAR (photosynthetically active radiation) on a $12 \mathrm{~h}$ light: $12 \mathrm{~h}$ dark cycle in $250 \mathrm{~mL}$ Erlenmeyer flasks. Irradiance was delivered by Osram Fluora $36 \mathrm{~W}$ (Munich, Germany) and Philips Daylight $36 \mathrm{~W}$ (Amsterdam, The Netherlands). They were periodically fed on a basis of a 1:1 ratio (predator: prey) with the marine ciliate Mesodinium rubrum (MrDK-2009) isolated from Helsingør harbor (Denmark) in 2009. The cryptophyte Teleaulax amphioxeia (AND-0710) isolated in 2007 from Huelva (Southwest Spain) was added as prey to the ciliate twice a week. The cryptophyte and the ciliate were grown in L1 -Si medium. All cultures were non- axenic.

\subsection{Determination of growth rate}

Cell densities were determined on five culture triplicates of $D$. acuta, $D$. caudata and $D$. tripos and two subclades of $D$. acuminata-complex, the cells were counted in $10 \mathrm{~mL}$ sedimentation chambers under a Zeiss Invertoskop D microscope (Carl Zeiss AG, Oberkochen, Germany), after fixation with acidic Lugol's solution.

The average growth rates $\left(\mu\right.$, day $\left.^{-1}\right)$ of Dinophysis species were calculated over exponential growth as $\mu=\ln \left(C_{2} / C_{1}\right) / t_{2}-t_{1}$ where $C 2$ and $\mathrm{C} 1$ are the concentrations of the cells (cell. $\mathrm{mL}^{-1}$ ) at experimental time 2 and time 1 (day) and $\mu\left(\right.$ day $^{-1}$ ) is the growth rate (Guillard, 1973).

\subsection{Microscopy observations}

Living cells of the strains studied were observed and measured using a Zeiss Axio Observer D microscope (Carl Zeiss Microscopy, Jena, Germany) equipped with an AxioCam $\mathrm{MrC}$ camera. Measurements were taken as the largest dimensions of cell body (i.e. length and depth in lateral views), excluding cingular and sulcal lists.

For scanning electron microscopy, cells from the cultures were fixed with $2 \%$ formaldehyde and then washed several times in deionized water purified at $18 \mathrm{M} \Omega \cdot \mathrm{cm}^{-1}$ through a Milli-Q integral 3 system (Merck Millipore, Meyzieu, France). Then, they were filtered on membranes $(1.2 \mu \mathrm{m}$ pores, $19 \mathrm{~mm}$ diameter, Merck Millipore, Meyzieu, France), and subsequently processed as described in Chomérat et al. (2019).

\subsection{Amplification and sequencing}

DNA amplification and sequencing was performed on 24 strains maintained in culture (Table 1). Due to the mixotrophic nature of Dinophysis spp. and in order to avoid any contaminations by preys, individual cells were isolated from live cultures by pipetting under an inverted microscope IX51 (Olympus, Tokyo, Japan). Then, they were rinsed in several drops of nuclease-free distilled water, and transferred into a $0.2 \mathrm{~mL}$ PCR tube. Nuclear ribosomal genes (ITS-5.8S region and LSU D1-D2) and mitochondrial (mtDNA) cytochrome $c$ oxidase I gene (cox1) were amplified to allow the characterization from both markers. To increase the number of amplicons, semi-nested-PCR reactions were performed. After the first amplification step, a second amplification was carried out using $1 \mu \mathrm{L}$ of the PCR product of the first reaction as template, and primers that bind to the target located within the sequence amplified at the first PCR step.

The PCR reaction mixtures $(25 \mu \mathrm{L})$ contained 1 cell of Dinophysis, 12.5 $\mu \mathrm{L}$ of PCR Master Mix (Promega, Foster City, CA, USA), $6.5 \mu \mathrm{L}$ of DNA free water and $2.5 \mu \mathrm{L}$ of forward and reverse $(10 \mathrm{nM})$. For the second round of PCR, $1 \mu \mathrm{L}$ of the amplicon produced in the first step was used as template. Primers used for both rounds of PCR amplifications are given in Table 2. Amplifications were carried out in a thermocycler Tprofessional (Biometra, Göttingen, Germany) with an initial denaturation at $95^{\circ} \mathrm{C}$ for $10 \mathrm{~min}, 35$ cycles at $95^{\circ} \mathrm{C}$ for $1 \mathrm{~min}, 62^{\circ} \mathrm{C}$ for $1 \mathrm{~min}$ and $72{ }^{\circ} \mathrm{C}$ for $3 \mathrm{~min}$, followed by a $10 \mathrm{~min}$ extension step at $72^{\circ} \mathrm{C}$.

PCR-amplified products were visualized on an agarose gel after electrophoresis and the positive samples were purified using the ExoSAP-IT PCR Product Cleanup reagent (Affymetrix, Cleveland, OH, USA).The Big Dye Terminator v3.1 Cycle Sequencing Kit (Applied Biosystems, Tokyo, Japan) was used for sequencing the amplicon generated at the second round of PCR. Primers and excess dye-labelled nucleotides were first removed using the Big Dye X-terminator purification kit (Applied Biosystems, Foster City, CA, USA). Sequencing products were run on an ABI PRISM 3130 Genetic Analyzer (Applied Biosystems).

\subsection{Alignment and phylogenetic analyses}

Sequences obtained for the 24 strains studied have been used in two distinct datasets (ITS-5.8S region and LSU rDNA, and cox1) for phylogenetic reconstructions, i.e. all $D$. acuminata and $D$. sacculus strains and at least one strain each of the three morphologically easily identifiable species (D. acuta, D. caudata and D. tripos). For the ITS $-5.8 \mathrm{~S}$ region and LSU rDNA, sequences of the 24 strains were aligned with 52 sequences of Dinophysis spp. retrieved in GenBank and Phalacroma rapa as external group, using MUSCLE algorithm in the MEGA X software version 10.1.7 (Kumar et al., 2018). This step was followed by refinement by eye. The resulting matrix included 77 sequences and 1633 aligned positions (including gaps). For the $\operatorname{cox} 1$ dataset, a matrix of 52 sequences and 718 characters was obtained by alignment with Clustal W using the MEGA software.

For each data set, evolutionary models were examined using maximum likelihood (ML) and Bayesian Inference analysis (BI). The evolutionary model was selected using jModelTest version 2.1.10 (Darriba et al., 2012). According to Akaike information criterion (AIC) and Bayesian information criterion (BIC), a general time reversible (GTR) model with a gamma correction (G) for among-site rate variation and no invariant sites was chosen for the ITS-LSU dataset while a Tamura-Nei model (TN93) with no invariant sites was chosen for the $\operatorname{cox} 1$ dataset.

Maximum likelihood analyses were performed using PhyML version 3.0 (Guindon et al., 2010), and Bayesian analyses were run using $\mathrm{Mr}$ Bayes version 3.1.2 (Ronquist and Huelsenbeck, 2003). Parameters used in each analysis are given in supplementary Table S1. Bootstrap analysis (1000 pseudoreplicates) was used to assess the relative robustness of branches of the ML tree. Initial Bayesian analyses were run with a GTR model (nst=6) with rates set to gamma for both datasets. Each analysis 
Table 1

List of the thirty strains of Dinophysis sp isolated from French coast during this study.

\begin{tabular}{|c|c|c|c|c|c|c|c|c|c|c|}
\hline \multirow[t]{2}{*}{ Strain } & \multirow[t]{2}{*}{ Species } & \multirow{2}{*}{$\begin{array}{l}\text { Collection date } \\
(\mathrm{m} / \mathrm{y})\end{array}$} & \multirow[t]{2}{*}{ Origin } & \multirow[t]{2}{*}{ Coordinates } & \multicolumn{2}{|c|}{ GenBank accession \# } & \multicolumn{4}{|c|}{ Toxin present } \\
\hline & & & & & LSU & $\cos 1$ & $\mathrm{AO}$ & $\begin{array}{l}\text { C9-diol } \\
\text { OA }\end{array}$ & DTX2 & PTX2 \\
\hline $\begin{array}{l}\text { IFR-DAU- } \\
\text { 03An }\end{array}$ & $\begin{array}{l}\text { D. acuminata } \\
\text { complex }\end{array}$ & Aug-19 & Antifer & $\begin{array}{l}49.66575 \mathrm{~N} \\
0.131659 \mathrm{E}\end{array}$ & МT365093 & MT371856 & + & $<\mathrm{LOD}$ & $<$ LOD & $<$ LOD \\
\hline $\begin{array}{l}\text { IFR-DAU- } \\
\text { 01Es }\end{array}$ & $\begin{array}{l}\text { D. acuminata } \\
\text { complex }\end{array}$ & Aug-19 & Saint Aubin - les Essarts & $\begin{array}{l}49.36424 \mathrm{~N} \\
0.38901 \mathrm{~W}\end{array}$ & MT365094 & MT371857 & + & $<\mathrm{LOD}$ & $<\mathrm{LOD}$ & $<\mathrm{LOD}$ \\
\hline $\begin{array}{l}\text { IFR-DAU- } \\
01 \mathrm{Ca}\end{array}$ & $\begin{array}{l}\text { D. acuminata } \\
\text { complex }\end{array}$ & Aug-19 & Cabourg & $\begin{array}{l}49.29840 \mathrm{~N} \\
0.11700 \mathrm{~W}\end{array}$ & МT365095 & MT371858 & + & $<\mathrm{LOD}$ & $<$ LOD & $<$ LOD \\
\hline $\begin{array}{l}\text { IFR-DAU- } \\
01 \mathrm{Ke}\end{array}$ & $\begin{array}{l}\text { D. acuminata } \\
\text { complex }\end{array}$ & May-18 & Kervel & $\begin{array}{l}48.11279 \mathrm{~N} \\
4.29085 \mathrm{~W}\end{array}$ & MT365096 & MT371859 & + & $<\mathrm{LOD}$ & $<$ LOD & $<\mathrm{LOD}$ \\
\hline $\begin{array}{l}\text { IFR-DAU- } \\
\text { 01Du }\end{array}$ & $\begin{array}{l}\text { D. acuminata } \\
\text { complex }\end{array}$ & Oct-17 & Dumet & $\begin{array}{l}47.42272 \mathrm{~N} \\
2.59545 \mathrm{~W}\end{array}$ & МT365097 & MT371860 & + & $<$ LOD & $<$ LOD & $<$ LOD \\
\hline $\begin{array}{c}\text { IFR-DAU- } \\
\text { 02Bm }\end{array}$ & $\begin{array}{l}\text { D. acuminata } \\
\text { complex }\end{array}$ & Apr-19 & Le Croisic & $\begin{array}{l}47.22916 \mathrm{~N} \\
2.58333 \mathrm{~W}\end{array}$ & МT365098 & MT371861 & + & $<\mathrm{LOD}$ & $<\mathrm{LOD}$ & $<\mathrm{LOD}$ \\
\hline $\begin{array}{l}\text { IFR-DAU- } \\
\text { 01Bo }\end{array}$ & $\begin{array}{l}\text { D. acuminata } \\
\text { complex }\end{array}$ & Apr-19 & Noirmoutier & $\begin{array}{l}47.01908 \mathrm{~N} \\
2.199944 \mathrm{~W}\end{array}$ & MT365099 & MT371862 & + & $<$ LOD & $<$ LOD & $<$ LOD \\
\hline $\begin{array}{l}\text { IFR-DAU- } \\
\text { 02Ar }\end{array}$ & $\begin{array}{l}\text { D. acuminata } \\
\text { complex }\end{array}$ & May-18 & Arcachon & $\begin{array}{l}44.54228 \mathrm{~N} \\
1.26374 \mathrm{~W}\end{array}$ & МT365100 & MT371863 & + & $<$ LOD & $<$ LOD & $<$ LOD \\
\hline $\begin{array}{l}\text { IFR-DSA- } \\
\text { 01Co }\end{array}$ & $\begin{array}{l}\text { D. acuminata } \\
\text { complex }\end{array}$ & Jul-19 & Concarneau & $\begin{array}{l}47.83341 \mathrm{~N} \\
3.94992 \mathrm{~W}\end{array}$ & MT365101 & MT371864 & + & $<$ LOD & $<\mathrm{LOD}$ & + \\
\hline $\begin{array}{l}\text { IFR-DSA- } \\
\text { 01Lo }\end{array}$ & $\begin{array}{l}\text { D. acuminata } \\
\text { complex }\end{array}$ & May-16 & Loscolo & $\begin{array}{l}47.40275 \mathrm{~N} \\
2.73007 \mathrm{~W}\end{array}$ & MT365102 & MT371865 & + & + & $<$ LOD & + \\
\hline $\begin{array}{l}\text { IFR-DSA- } \\
01 \mathrm{Me}\end{array}$ & $\begin{array}{l}\text { D. acuminata } \\
\text { complex }\end{array}$ & May-15 & Arcachon & $\begin{array}{l}44.64769 \mathrm{~N} \\
1.10039 \mathrm{~W}\end{array}$ & MT365103 & MT371866 & + & + & $<$ LOD & + \\
\hline $\begin{array}{l}\text { IFR-DSA- } \\
\text { 01Lt }\end{array}$ & $\begin{array}{l}\text { D. acuminata } \\
\text { complex }\end{array}$ & May-15 & La Teste de Buch & $\begin{array}{l}44.64589 \mathrm{~N} \\
1.14531 \mathrm{~W}\end{array}$ & МT365104 & MT371867 & + & + & $<\mathrm{LOD}$ & + \\
\hline $\begin{array}{l}\text { IFR-DSA- } \\
01 \mathrm{Th}\end{array}$ & $\begin{array}{l}\text { D. acuminata } \\
\text { complex }\end{array}$ & Dec-15 & Thau Lagoon & $\begin{array}{l}43.44731 \mathrm{~N} \\
3.67054 \mathrm{E}\end{array}$ & MT365105 & MT371868 & + & + & $<$ LOD & + \\
\hline $\begin{array}{l}\text { IFR-DSA- } \\
\text { 02Th }\end{array}$ & $\begin{array}{l}\text { D. acuminata } \\
\text { complex }\end{array}$ & Oct-17 & Thau Lagoon & $\begin{array}{l}43.44731 \mathrm{~N} \\
3.67054 \mathrm{E}\end{array}$ & MT365106 & MT371869 & + & + & $<$ LOD & + \\
\hline $\begin{array}{l}\text { IFR-DSA- } \\
\text { 03Th }\end{array}$ & $\begin{array}{l}\text { D. acuminata } \\
\text { complex }\end{array}$ & Mar-18 & Thau Lagoon & $\begin{array}{l}43.44731 \mathrm{~N} \\
3.67054 \mathrm{E}\end{array}$ & МT365107 & MT371870 & + & $<\mathrm{LOD}$ & $<$ LOD & + \\
\hline $\begin{array}{l}\text { IFR-DSA- } \\
01 \mathrm{Vp}\end{array}$ & $\begin{array}{l}\text { D. acuminata } \\
\text { complex }\end{array}$ & Mar-18 & Vic Lagoon & $\begin{array}{l}43.49147 \mathrm{~N} \\
3.82587 \mathrm{E}\end{array}$ & MT365108 & MT371871 & + & $<\mathrm{LOD}$ & $<\mathrm{LOD}$ & + \\
\hline $\begin{array}{l}\text { IFR-DSA- } \\
\text { 01Po }\end{array}$ & $\begin{array}{l}\text { D. acuminata } \\
\text { complex }\end{array}$ & Mar-18 & Ponant Lagoon & $\begin{array}{l}43.55907 \mathrm{~N} \\
4.10167 \mathrm{E}\end{array}$ & МТ365109 & MT371872 & + & $<\mathrm{LOD}$ & $<$ LOD & + \\
\hline $\begin{array}{l}\text { IFR-DSA- } \\
01 \mathrm{Ma}\end{array}$ & $\begin{array}{l}\text { D. acuminata } \\
\text { complex }\end{array}$ & Mar-18 & Berre Lagoon & $\begin{array}{l}43.46871 \mathrm{~N} \\
5.02094 \mathrm{E}\end{array}$ & MT365110 & MT371873 & + & + & $<$ LOD & + \\
\hline $\begin{array}{l}\text { IFR-DSA- } \\
01 \mathrm{Lj}\end{array}$ & $\begin{array}{l}\text { D. acuminata } \\
\text { complex }\end{array}$ & Mar-18 & Berre Lagoon & $\begin{array}{l}43.40813 \mathrm{~N} \\
5.15436 \mathrm{E}\end{array}$ & MT365111 & MT371874 & + & + & $<$ LOD & + \\
\hline $\begin{array}{l}\text { IFR-DTR- } \\
01 \mathrm{Ar}\end{array}$ & D. tripos & Apr-19 & Arcachon & $\begin{array}{l}44.54228 \mathrm{~N} \\
1.26374 \mathrm{~W}\end{array}$ & МТ365115 & MT371875 & $<$ LOD & $<\mathrm{LOD}$ & $<$ LOD & + \\
\hline $\begin{array}{l}\text { IFR-DCA- } \\
01 \mathrm{Ke}\end{array}$ & D. caudata & Oct-17 & Kervel & $\begin{array}{l}48.11279 \mathrm{~N} \\
4.29085 \mathrm{~W}\end{array}$ & - & - & $<\mathrm{LOD}$ & $<$ LOD & $<$ LOD & + \\
\hline $\begin{array}{l}\text { IFR-DCA- } \\
03 \mathrm{Ke}\end{array}$ & D. caudata & Oct-17 & Kervel & $\begin{array}{l}48.11279 \mathrm{~N} \\
4.29085 \mathrm{~W}\end{array}$ & - & - & $<$ LOD & $<$ LOD & $<\mathrm{LOD}$ & + \\
\hline $\begin{array}{l}\text { IFR-DCA- } \\
\text { 02Lo }\end{array}$ & D. caudata & Oct-17 & Loscolo & $\begin{array}{l}47.40275 \mathrm{~N} \\
2.73007 \mathrm{~W}\end{array}$ & - & - & $<$ LOD & $<$ LOD & $<\mathrm{LOD}$ & + \\
\hline $\begin{array}{l}\text { IFR-DCA- } \\
\text { 04Tr }\end{array}$ & D. caudata & Aug-19 & $\begin{array}{l}\text { Grand Travers beach (La } \\
\text { Grande Motte) }\end{array}$ & $\begin{array}{l}43.55631 \mathrm{~N} \\
4.03588 \mathrm{E}\end{array}$ & MT365116 & MT371876 & $<\mathrm{LOD}$ & $<\mathrm{LOD}$ & $<$ LOD & + \\
\hline $\begin{array}{l}\text { IFR-DAC- } \\
\text { 03Ke }\end{array}$ & D. acuta & Nov-17 & Kervel & $\begin{array}{l}48.11279 \mathrm{~N} \\
4.29085 \mathrm{~W}\end{array}$ & MT365112 & MT371877 & + & $<\mathrm{LOD}$ & + & + \\
\hline $\begin{array}{l}\text { IFR-DAC- } \\
\text { 02LC }\end{array}$ & D. acuta & Aug-17 & Le Croisic & $\begin{array}{l}47.30343 \mathrm{~N} \\
2.53849 \mathrm{~W}\end{array}$ & MT365113 & MT371878 & + & $<\mathrm{LOD}$ & + & + \\
\hline $\begin{array}{l}\text { IFR-DAC- } \\
\text { 03Lc }\end{array}$ & D. acuta & Aug-17 & Le Croisic & $\begin{array}{l}47.30343 \mathrm{~N} \\
2.53849 \mathrm{~W}\end{array}$ & - & - & + & $<\mathrm{LOD}$ & + & + \\
\hline $\begin{array}{l}\text { IFR-DAC- } \\
\text { 04LC }\end{array}$ & D. acuta & Oct-17 & Le Croisic & $\begin{array}{l}47.30343 \mathrm{~N} \\
2.53849 \mathrm{~W}\end{array}$ & - & - & + & $<$ LOD & + & + \\
\hline $\begin{array}{l}\text { IFR-DAC- } \\
\text { 01Ar }\end{array}$ & D. acuta & Aug-17 & Arcachon & $\begin{array}{l}44.54228 \mathrm{~N} \\
1.26374 \mathrm{~W}\end{array}$ & МT365114 & MT371879 & + & $<$ LOD & + & + \\
\hline $\begin{array}{l}\text { IFR-DAC- } \\
\text { 01Po }\end{array}$ & D. acuta & Jul-18 & Ponant Lagoon & $\begin{array}{l}43.55907 \mathrm{~N} \\
4.10167 \mathrm{E}\end{array}$ & - & - & + & $<\mathrm{LOD}$ & + & + \\
\hline
\end{tabular}

was performed using four Markov chains (MCMC), with four millions cycles for each chain. Trees were saved every 100 cycles and the first 4000 trees were discarded. Therefore, a majority-rule consensus tree was created from the remaining 36,001 trees in order to examine the posterior probabilities of each clade. Bootstraps values below 65 and posterior probabilities below 0.70 representing absence of support were not shown but indicated as '-'.

The consensus trees were edited using Seaview. The best ML phylograms are shown with robustness values for each node (ML/BI).

\subsection{Toxin analysis}

\subsubsection{Reagent and chemicals}

Formic acid (FA, 98\%) and ammonium formate (10 M in solution) were purchased from Sigma Aldrich (Darmstadt, Germany), Acetonitrile (ACN) and methanol (MeOH) was purchased from Honeywell (Seelze, Germany). Water was deionized and purified at $18 \mathrm{M} \Omega \cdot \mathrm{cm}^{-1}$ through a Milli-Q integral 3 system (Merck Millipore, Meyzieu, France). Certified reference materials (OA, DTX1, DTX2, and PTX2) were purchased from the National Research Council Canada (NRC-CNRC, Halifax, Nova 
Table 2

Primers used for DNA amplification in the two rounds of the semi-nested/nested PCR.

\begin{tabular}{|c|c|c|c|}
\hline Primer & Sequence $\left(5^{\prime}-3^{\prime}\right)$ & $\begin{array}{l}\text { PCR } \\
\text { rounds }\end{array}$ & Reference \\
\hline ITSFW & GTA GGT GAA CCT GCG GAA GG & 1,2 & $\begin{array}{l}\text { Adam et al., } \\
2000\end{array}$ \\
\hline D3B & TCG GAG GGA ACC AGC TAC TA & 1 & $\begin{array}{l}\text { Nunn et al., } \\
1996\end{array}$ \\
\hline D2C & CCT TGG TCC GTG TTT CAA GA & 2 & $\begin{array}{l}\text { Scholin et al., } \\
1994\end{array}$ \\
\hline Dinocox1F & $\begin{array}{l}\text { AAA AAT TGT AAT CAT AAA CGC } \\
\text { TTA GG }\end{array}$ & 1,2 & Lin et al., 2002 \\
\hline Dinocox1R & $\begin{array}{l}\text { TGT TGA GCC ACC TAT AGT AAA } \\
\text { CAT TA }\end{array}$ & 1 & Lin et al., 2002 \\
\hline Cox777R & CAT TGA TTG GTT CSC AAA GA & 2 & This study \\
\hline
\end{tabular}

Scotia, Canada) and the non-certified C8-diol ester of OA were purchased from Cifga (via Novakits, Nantes, France).

\subsubsection{Extraction procedures}

Samples $(10 \mathrm{~mL})$ of Dinophysis culture were collected at the end of the exponential growth phase and centrifuged at $3500 \mathrm{~g}, 4^{\circ} \mathrm{C}$ for $15 \mathrm{~min}$. The supernatant was removed and cell pellets were extracted twice with $0.5 \mathrm{~mL} \mathrm{MeOH}$ using an ultrasonic bath (Elma, Singen, Germany) at 25 $\mathrm{KHz}$ during $15 \mathrm{~min}$ in sweep mode. Once cells were disrupted, the supernatants were collected and combined after centrifugation (at $3500 \mathrm{~g}$, $\left.4{ }^{\circ} \mathrm{C}, 15 \mathrm{~min}\right)$. The final extracts $(0.5 \mathrm{~mL})$ were filtered through a Nanosep MF $0.2 \mu \mathrm{m}$ filter (Pall, Northborough, MA, USA), and stored at $-20^{\circ} \mathrm{C}$ until LC-MS/MS analysis.
2.7.3. Liquid chromatography coupled to tandem mass spectrometry

LC-MS/MS analysis were performed using a HPLC system (UFLC XR Nexera, Shimadzu, Japan) coupled to a hybrid triple quadrupole/iontrap mass spectrometer API 4000 QTrap (SCIEX, Redwood City, CA, USA) equipped with a turboV ${ }^{\circledR}$ ESI source.

Chromatographic separation was carried out on a reversed-phase C18 Kinetex column $(100 \AA ̊ 丿, 2.6 \mu \mathrm{m}, 50 \times 2.1 \mathrm{~mm}$, Phenomenex, LePecq, France) at $40{ }^{\circ} \mathrm{C}$ using a mobile phase composed of water (A) and $95 \%$ acetonitrile/water (B) both containing $5 \mathrm{mM}$ ammonium formate and $50 \mathrm{mM}$ formic acid. The flow rate was set to $0.4 \mathrm{~mL} \cdot \mathrm{min}^{-1}$ and the injection volume was $5 \mu \mathrm{L}$. Mass spectrometric detection was performed in either negative or positive ionization mode using Multiple Reaction Monitoring (MRM) scanning. To achieve a better separation and sensitivity for each toxin group, three LC-MS/MS methods were created (for ESI parameters and the $m / z$ transitions see Table 3 ). The gradients were described as follows:

(i) For OA and DTX analogs, mobile phase was raised from $10 \%$ to $50 \% \mathrm{~B}$ in $2 \mathrm{~min}$, to $90 \% \mathrm{~B}$ over the next $4.5 \mathrm{~min}$, then held for $1 \mathrm{~min}$ before return to the initial condition $(10 \% \mathrm{~B})$ followed by a re-equilibration period of $3.5 \mathrm{~min}$.

(ii) For PTXs, mobile phase was held for $1 \mathrm{~min}$ at $10 \% \mathrm{~B}$, then raised from $10 \%$ to $60 \%$ B in $2 \mathrm{~min}$, and to $90 \%$ B over the next $4 \mathrm{~min}$, held for $2 \mathrm{~min}$ before return to the initial condition $(10 \% \mathrm{~B})$ followed by a re-equilibration period $(10 \% \mathrm{~B})$ of $3.0 \mathrm{~min}$.

(iii) For OA diol esters, separation was achieved using a mobile phase gradient from $10 \%$ to $50 \%$ B in $2 \mathrm{~min}$, to $95 \%$ B over the next $4.5 \mathrm{~min}$, held for $3.5 \mathrm{~min}$ before return to the initial condition $(10 \% \mathrm{~B})$ in $1 \mathrm{~min}$ and a re-equilibration period $(10 \% \mathrm{~B})$ of $5 \mathrm{~min}$.

The instrument control, data processing and analysis were conducted

Table 3

Settings of mass spectrometric parameters (collision energy (CE); exit potential (CXP)), MRM transitions monitored in API 4000QTrap instrument (SCIEX, CA, USA) and the limits of detection (LOD) and quantification (LOQ) for the standards available.

\begin{tabular}{|c|c|c|c|c|c|c|c|}
\hline Group & Source settings & Toxin & MRM transitions $(\mathrm{m} / \mathrm{z})$ & $\mathrm{CE}(\mathrm{eV})$ & $\mathrm{CXP}(\mathrm{eV})$ & $\begin{array}{l}\text { LOD } \\
\text { (ng } \mathrm{mL}^{-1} \text { ) }\end{array}$ & $\begin{array}{l}\text { LOQ } \\
\left(\mathrm{ngmL}^{-1}\right)\end{array}$ \\
\hline \multirow[t]{13}{*}{ OA diol ester } & \multirow[t]{2}{*}{ Mode ESI $^{+}$} & \multirow[t]{2}{*}{ C9-diol OA } & $965.4 / 827.4^{*}$ & 50 & 11 & & \\
\hline & & & $965.4 / 723.4$ & 62 & 16 & & \\
\hline & \multirow[t]{2}{*}{ CUR (psi) 30} & \multirow[t]{2}{*}{ C9-triol OA } & $981.4 / 827.4^{*}$ & 50 & 11 & & \\
\hline & & & $981.4 / 723.4$ & 62 & 16 & & \\
\hline & \multirow[t]{2}{*}{ TEMP $\left({ }^{\circ} \mathrm{C}\right) 500$} & \multirow[t]{3}{*}{ C8-diol OA } & $946.6 / 805.6^{*}$ & 17 & 22 & 1.5 & 4 \\
\hline & & & $946.6 / 751.6$ & 35 & 20 & & \\
\hline & \multirow[t]{2}{*}{ GS1 (psi) 50} & & $946.6 / 787.6$ & 21 & 20 & & \\
\hline & & C7-diol OA & $937.4 / 827.4^{*}$ & 50 & 11 & & \\
\hline & \multirow{2}{*}{ GS2 (psi) 50} & & $937.4 / 723.4$ & 62 & 16 & & \\
\hline & & C6-diol OA & $923.4 / 827.4^{*}$ & 50 & 11 & & \\
\hline & \multirow[t]{2}{*}{ IS (V) 5500} & & $923.4 / 723.4$ & 62 & 16 & & \\
\hline & & C4-diol OA & $897.4 / 827.4^{*}$ & 50 & 11 & & \\
\hline & DP (V) 66 & & $897.4 / 723.4$ & 62 & 16 & & \\
\hline \multirow[t]{6}{*}{ OA and DTXs } & Mode ESI $^{-}$ & AO, DTX2 & $803.4 / 255.1^{*}$ & -62 & -16 & 1 & 3 \\
\hline & \multicolumn{2}{|l|}{ CUR (psi) 25} & & & & & \\
\hline & \multicolumn{2}{|l|}{ TEMP $\left({ }^{\circ} \mathrm{C}\right) 600 \mathrm{GS} 1$ (psi) 40} & $803.4 / 113.1$ & -92 & -9 & & \\
\hline & GS2 (psi) 60 & \multirow[t]{3}{*}{ DTX1 } & $817.3 / 255.4^{*}$ & -64 & -9 & 1 & 3 \\
\hline & IS (V) -4500 & & & & & & \\
\hline & $\mathrm{DP}(\mathrm{V})-170$ & & $817.3 / 113.2$ & -92 & -10 & & \\
\hline \multirow[t]{13}{*}{ PTXs } & \multirow[t]{2}{*}{ Mode ESI $^{+}$} & \multirow[t]{3}{*}{ PTX2 } & $876.6 / 823.5^{*}$ & 31 & 12 & 0.2 & 0.6 \\
\hline & & & $876.6 / 805.6$ & 37 & 12 & & \\
\hline & \multirow[t]{2}{*}{ CUR (psi) 30} & & $876.6 / 213.6$ & 55 & 12 & & \\
\hline & & PTX2sa & $894.6 / 823.5^{*}$ & 31 & 12 & & \\
\hline & \multirow[t]{2}{*}{ TEMP $\left({ }^{\circ} \mathrm{C}\right) 450$} & \multirow[t]{2}{*}{ 7-epi-PTX2sa } & $894.5 / 805.5$ & 37 & 12 & & \\
\hline & & & $894.5 / 213.6$ & 55 & 12 & & \\
\hline & \multirow[t]{2}{*}{ GS1 (psi) 50} & PTX1 & $892.6 / 821.4$ & 37 & 12 & & \\
\hline & & PTX4 & $892.6 / 839.5^{*}$ & 31 & 12 & & \\
\hline & \multirow[t]{2}{*}{ GS2 (psi) 50} & PTX11 PTX13 & $892.6 / 213.6$ & 55 & 12 & & \\
\hline & & PTX6 & $906.6 / 871.6^{*}$ & 31 & 12 & & \\
\hline & \multirow[t]{2}{*}{ IS (V) 5500} & PTX7 & $906.6 / 853.6$ & 37 & 12 & & \\
\hline & & PTX12 PTX14 & $874.5 / 839.6^{*}$ & 31 & 12 & & \\
\hline & DP (V) 91 & & $874.6 / 213.6$ & 55 & 12 & & \\
\hline
\end{tabular}

\footnotetext{
" MRM transition used for quantification in each method
} 
using Analyst software 1.6.3 (Sciex, Redwood City, CA, USA). Due to the lack of standards, quantification was performed using linear calibration curves generated from reference standards of OA, DTX2, DTX1, PTX2 and C8-diol ester of OA. The limits of detection (LODs) and quantification (LOQs) for available standards were determined with the ordinary least-squares regression method (Sanagi et al., 2009; Vial and Jardy, 1999) (Table 3), and also recorded on a cellular basis [pg.cell ${ }^{-1}$ ] (Table S2).

\section{Results}

\subsection{Taxonomic identification of French strains of Dinophysis spp}

\subsubsection{Molecular phylogenetic data}

The phylogenetic analysis inferred from the LSU rDNA nuclear gene revealed that the sequences obtained for 24 French strains clustered in four different clades. Nineteen sequences clustered into a group of

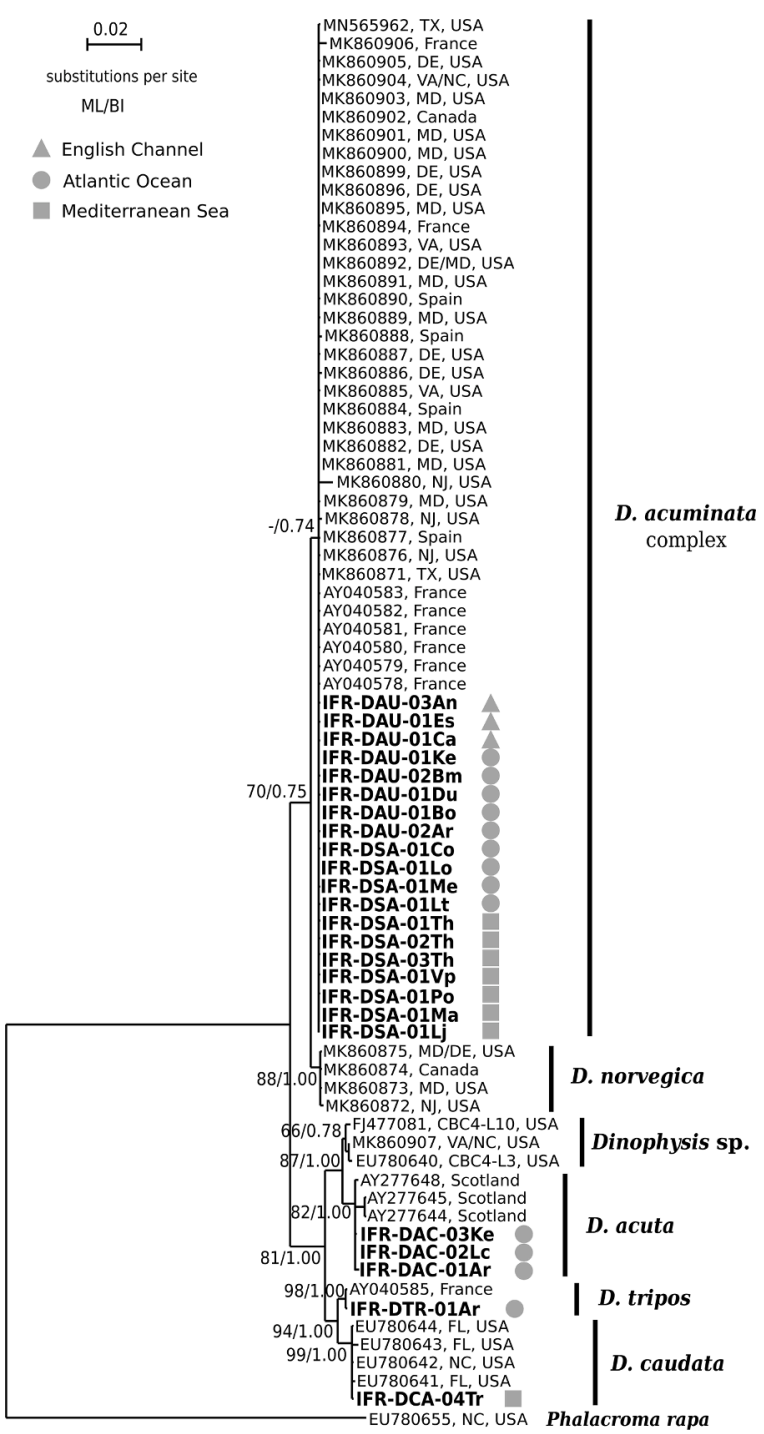

Fig. 2. Maximum Likelihood phylogenetic tree inferred from ITS-LSU rDNA sequences of various Dinophysis spp. sequences (77 sequences, 1633 aligned positions). Sequences obtained in the present study are indicated by bold face and their origin by a symbol (triangle: English Channel, circle: Atlantic Ocean, square: Mediterranean Sea). Phalacroma rapa is used as an outgroup. Numbers at nodes represent bootstrap support values from Maximum Likelihood (ML) and posterior probabilities from Bayesian Inference (BI). Bootstraps values below 65 and posterior probabilities below 0.70 are shown as '-'. sequences identified as $D$. acuminata-complex, three sequences within $D$. acuta, one sequence within $D$. caudata and one within $D$. tripos (Fig. 2). Interestingly, all 19 sequences of the D. acuminata-complex were identical, and no difference was found with respect to their geographical origin (Fig. 2). Additionally, several sequences of this clade retrieved in GenBank have been ascribed to different names such as ' $D$. acuminata', 'D. ovum' (e.g. MN565962) and 'D. sacculus' (e.g. AY040583), but from a molecular point of view, they all appeared almost similar and impossible to distinguish based on sequence data.

The phylogenetic ML and BI trees inferred from cox 1 gene were congruent and the 24 sequences of French strains clustered into four clades (Fig. 3). The sequences of strains IFR-DTR-01Ar and IFR-DCA$04 \mathrm{Tr}$ identified as $D$. tripos and $D$. caudata, respectively, were identical and clustered together into a clade comprising $D$. miles, $D$. tripos and $D$. caudata, almost unsupported by the bootstrap values. Sequences of the three strains identified as $D$. acuta, namely IFR-DAC-03Ke, IFR-DAC02Lc and IFR-DAC-01Ar, grouped together with the sequence HQ681272 identified as $D$. acuta, with a moderate bootstrap support.

The remaining 19 sequences clustered in the $D$. acuminata-complex (Fig. 3). Within this clade, two subgroups of sequences were found: the subclade A included 8 strains from France ( 3 from English Channel and 5 from Atlantic Ocean), and 14 sequences from various origins (Korea, Greece, USA and Spain) identified as ' $D$. acuminata'. The subclade B comprised 11 sequences from French strains ( 4 from Atlantic Ocean and 7 from Mediterranean Sea) and two sequences from Spain (KC576782 and KY849911) identified as ' $D$. sacculus'. However, within the $D$. acuminata-complex, the sequences of these two subclades differed by only one nucleotide (at position 136), with a ' $G$ ' in all sequences of subclade A replaced by an 'A' in all sequences of subclade B (Fig. 4). This unique difference resulted in a poor resolution in the phylogenetic analysis and thereby a low bootstrap support of the branch (Fig. 3). Although they have a ' $G$ ' at position 136, as for all other sequences of subclade A, two Galician sequences were well divergent from all others of this subclade with 11 and 2 differences for sequences AM931582 and HQ681583, respectively.

\subsubsection{Morphological features and growth of D. acuta, D. caudata and D. tripos strains}

Cells of $D$. acuta strains had a typical outline with a wider depth ('width') under the median part, and a triangular shape at their posterior end (Fig. 5A). Cells of the strain IFR-DAC-01Ar were $67.1 \pm 2.0 \mu \mathrm{m}$ long and $46.4 \pm 2.7$ deep, with a $\mathrm{L} / \mathrm{D}$ ratio varying from 1.33 to 1.63 (Table 4).

Cells of $D$. caudata were easily recognized with their unique and prominent ventral projection of the hypotheca (Fig. 5B). Cells from strain IFR-DCA-04Tr were $81.8 \pm 2.4 \mu \mathrm{m}$ long and $43.3 \pm 1.9 \mu \mathrm{m}$ deep, with an L/D ratio varying from 1.75 to 2.03 (Table 4).

Cells of $D$. tripos were characterized by their large size and the presence of two antapical projections. The dorsal projection ('horn') was shorter than the ventral one which was more prominent (Fig. 5C). Cells of the strain IFR-DTR-01Ar were $97.6 \pm 3.0 \mu \mathrm{m}$ long and $48.7 \pm 3.3 \mu \mathrm{m}$ deep, with a L/D ratio varying from 1.78 to 2.37 (Table 4).

During the exponential growth phase, the average growth rates $(\mu)$ of the strains belonging to these three species ranged from $0.20 \pm 0.01$ day $^{-1}$ for $D$. caudata to $0.22 \pm 0.02$ day $^{-1}$ and $0.23 \pm 0.03$ day $^{-1}$ for $D$. tripos and D. acuta, respectively.

\subsubsection{Morphological features, variations and growth of strains of the D. acuminata-complex}

Cells that belong to strains of the D. acuminata-complex were more or less oval, with a variable shape of the dorsal margin from convex to straight (Fig. 6A-H). Among five strains studied for morphometry, average length ranged from 45.4 to $49.9 \mu \mathrm{m}$ while average depth ranged from 28.7 to $33.6 \mu \mathrm{m}$ (Table 4 ) and size did not appear significantly different among these strains (Mann-Whitney tests, not shown). In addition, the average growth rates of the two strains of the $D$. acuminata 


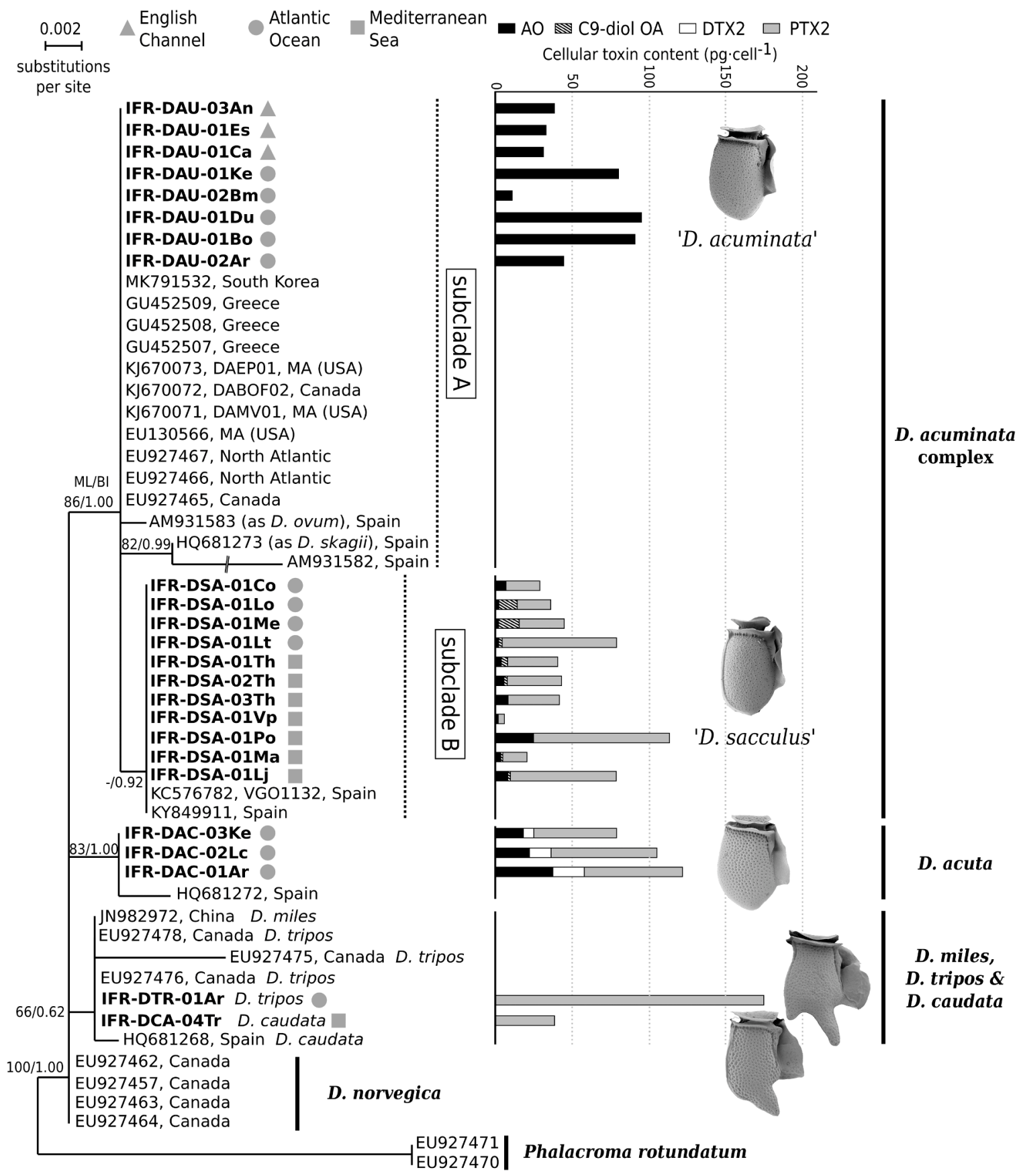

Fig. 3. Maximum Likelihood phylogenetic tree inferred from mitochondrial cox1 gene partial sequences (left panel) compared with the toxin composition of the French strains (right panel). ML tree includes 52 sequences and 718 aligned positions. Sequences obtained in the present study are indicated by bold face and their origin by a symbol (triangle: English Channel, circle: Atlantic Ocean, square: Mediterranean Sea). Phalacroma rotundatum sequences are used as an outgroup. Numbers at nodes represent bootstrap support values from Maximum Likelihood (ML) and posterior probabilities from Bayesian Inference (BI). Bootstraps values below 65 and posterior probabilities below 0.70 are shown as '-'. Toxin profiles and toxin content are expressed in pg.cell ${ }^{-1}$.

complex ranged from $0.41 \pm 0.02 \mathrm{day}^{-1}$ for the strain IFR-DAU-0.2Ar, clustering in subclade A putatively ascribed to ' $D$. acuminata' to $0.43 \pm 0.01$ day $^{-1}$ for the strain IFR-DSA-0.1 Lt clustering in subclade B (' $D$. sacculus'). Growth rates for these $D$. acuminata strains were thus twice as high as those of the aforementioned strains of $D$. caudata, $D$. tripos and D. acuta.

In order to further investigate morphological variations of strains within the $D$. acuminata-complex in relation with molecular data, the morphology of strains clustering in subclade A putatively ascribed to ' $D$. acuminata' (IFR-DAU-03An, IFR-DAU-01Es, IFR-DAU-01Ca, IFR-DAU$01 \mathrm{Ke}$ and IFR-DAU-02Ar) and subclade B putatively ascribed to ' $D$. sacculus' (IFR-DSA-01Lt, IFR-DSA-02Th) in the phylogeny inferred from cox 1 have been studied by SEM. In strains of subclade A, cells with an oval shape and a typical convex dorsal margin were observed in the strains from the English Channel (IFR-DAU-03An, IFR-DAU-01Es, IFRDAU-01Ca) (Fig. 6A-C). In strains from the Atlantic Ocean, the shape was more variable and some cells were more rectangular with a straight dorsal margin (Fig. 6D). Within strain IFR-DAU-02Ar (Fig. 6E-H), some specimens with a dorsal margin varying from convex on the posterior side (Fig. 6E-F) to straight (Fig. 6G-H) were observed. Depending on the age of the specimens, the ornamentation was found to be variable, from smooth (Fig. 6H) to conspicuously foveate (Fig. 6G). In the two strains of 


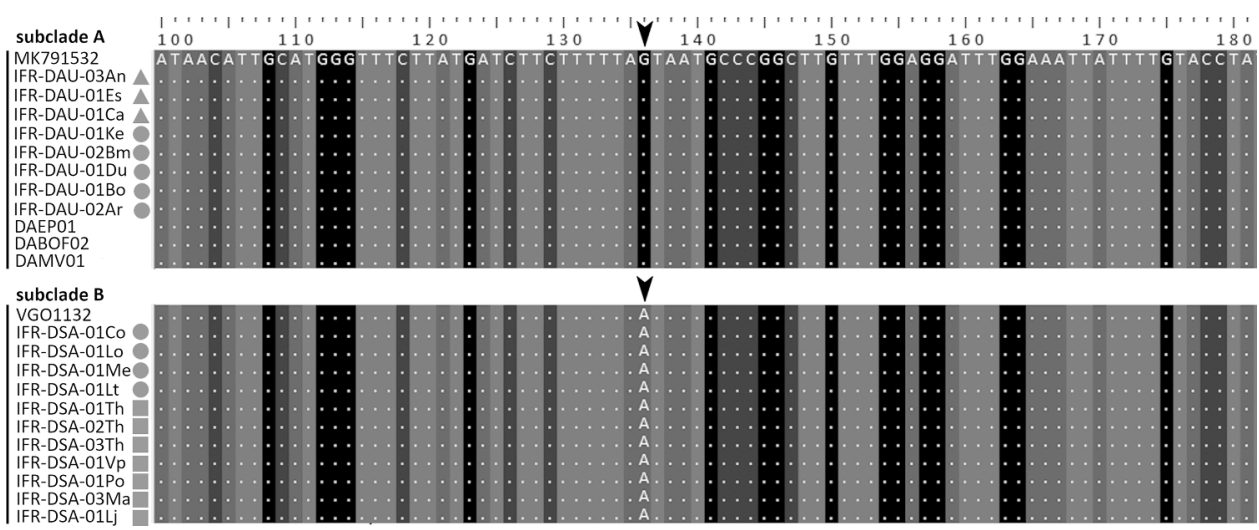

Fig. 4. Partial sequence alignment of the cox 1 gene from species of the $D$. acuminata-complex including 19 strains from the present study, the reference sequence MK791532 (Park et al., 2019) and 4 strains retrieved in GenBank for which toxin profiles are known (Table 5). Arrows indicate the single nucleotide substitution between the subclades A and B in the phylogenetic analysis. Geographic origin of the strains is shown with a symbol (triangle: English Channel, circle: Atlantic Ocean, square: Mediterranean Sea).
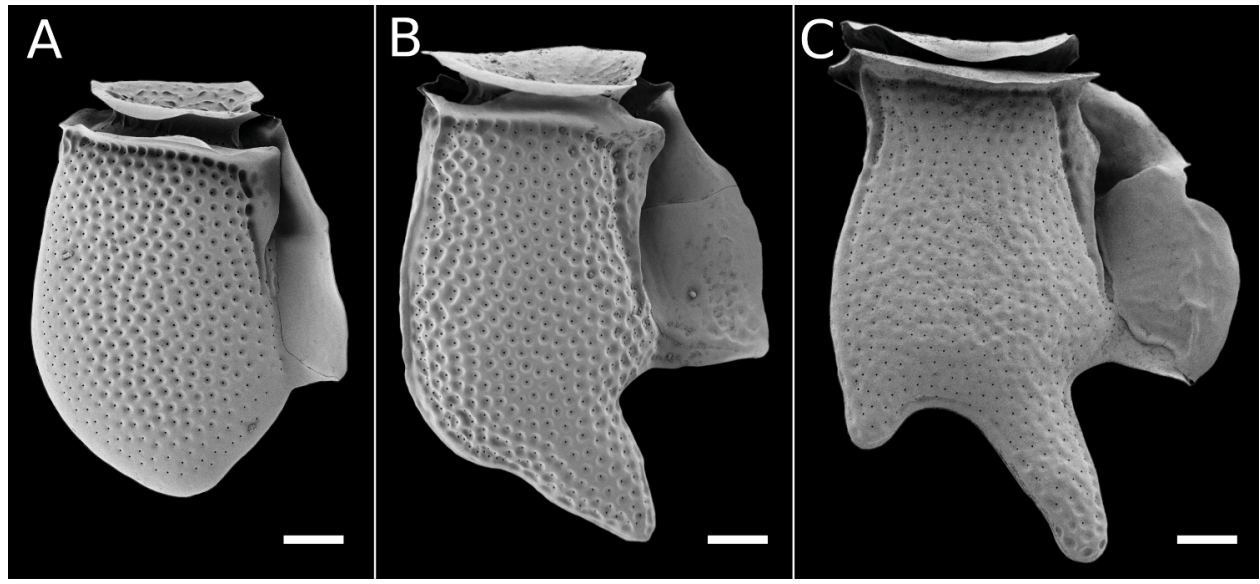

Fig. 5. SEM micrographs of $D$. acuta (strain IFR-DAC-03Ke), D. caudata (strain IFR-DCA-03Ke), D. tripos (strain IFR-DTR-01Ar) showing their typical morphology. Scale bars: $10 \mu \mathrm{m}$.

Table 4

Morphometric data and growth rates of 8 strains of the different species.

\begin{tabular}{|c|c|c|c|c|c|c|}
\hline Strain & Species & Length (mean \pm s.d.) $\mu \mathrm{m}$ & Depth (mean \pm s.d.) $\mu \mathrm{m}$ & L/D & $n$ & $\mu$ (mean, range) Day ${ }^{-1}$ \\
\hline IFR-DAU-03An & D. acuminata-complex & $45.6 \pm 2.3$ & $31.3 \pm 1.9$ & $1.35-1.67$ & 25 & ND \\
\hline IFR-DAU-01Ke & D. acuminata-complex & $49.9 \pm 3.6$ & $33.6 \pm 2.6$ & $1.30-1.71$ & 24 & ND \\
\hline IFR-DAU-02Ar & D. acuminata-complex & $45.5 \pm 5.3$ & $29.6 \pm 4.1$ & $1.23-1.79$ & 21 & $0.41,0.40-0.42$ \\
\hline IFR-DSA-02Th & D. acuminata-complex & $46.5 \pm 3.1$ & $30.4 \pm 1.8$ & $1.36-1.66$ & 25 & ND \\
\hline IFR-DAC-01Ar & D. acuta & $67.1 \pm 2.0$ & $46.4 \pm 2.7$ & $1.33-1.63$ & 25 & $0.23,0.21-0.26$ \\
\hline IFR-DCA-04Tr & D. caudata & $81.8 \pm 2.4$ & $43.3 \pm 1.9$ & $1.75-2.03$ & 26 & $0.20,0.19-0.21$ \\
\hline IFR-DTR-01Ar & D. tripos & $97.6 \pm 3.0$ & $48.7 \pm 3.3$ & $1.78-2.37$ & 25 & $0.22,0.21-0.24$ \\
\hline
\end{tabular}

subclade B analyzed, morphology was very variable among cells. In both strains IFR-DSA-01Lt from Atlantic Ocean (Fig. 7A-D) and IFR-DSA02Th from the Mediterranean area (Fig. 7E-H), a continuum of shapes was observed, including cells with a concave dorsal margin and a reniform shape (Fig. 7A, B, E), cells with a straight dorsal margin and almost rectangular (Fig. 7C, F) and cells with a convex dorsal margin (Fig. 7D, $\mathrm{G}-\mathrm{H})$. Hence, within-strain morphological variability was high in these strains.

\subsection{Toxin profiles}

In this study, LC-MS/MS analyses of toxin contents and profiles were carried out on all 30 Dinophysis strains isolated from different locations of the French coastal waters (English Channel, Atlantic Ocean, and Mediterranean Sea). Toxin profiles appeared remarkably conserved for each morphospecies, irrespective of their geographical origin, and five profiles could be identified (Figs. 3 and S1). Overall, the most abundant toxin was PTX2, being the major compound in D. tripos, D. caudata and D. acuta. Higher PTX2 contents per cell were found in D. tripos (176 $\mathrm{pg} \cdot \mathrm{cell}^{-1}$ ) and $D$. caudata (39-200 pg.cell ${ }^{-1}$ ) and no OA or DTXs were detected (Table S2). The toxin profile of $D$. acuta was characterized by the presence of DTX2 in all strains (Figs. 3 and S1), again with PTX2 as the major toxin $(>50 \%)$ and OA present in moderate to high amounts (10 - $\left.38 \mathrm{pg} \cdot \mathrm{cell}^{-1}\right)$. The Mediterranean strain, IFR-DAC-01Po, showed a low total toxin content $\left(24 \mathrm{pg} \cdot \mathrm{cell}^{-1}\right)$ by comparison with the other strains (59 - $149 \mathrm{pg} \cdot$ cell $^{-1}$ ) from the Atlantic Ocean (Table S2, Fig. S1).

Interestingly, within the $D$. acuminata-complex, two very different toxin profiles were observed (Fig. 3). The eight strains clustering within subclade A in $\operatorname{cox} 1$ phylogeny (i.e. 'D. acuminata', Fig. 3) contained only OA, with all other compounds below LOD (Table S2). The amount of OA varied greatly among the 8 strains analyzed, and, except for one strain, all others contained 32 to $96 \mathrm{pg} \cdot \mathrm{cell}^{-1}$ (Table S2). In contrast, the 11 
Table 5

Summary of the toxin profiles of D.acuminata-complex (mitochondrial gene cox 1 identified) from this study and literature.

\begin{tabular}{|c|c|c|c|c|c|c|}
\hline Strain & Origin & Subclade & $\mathrm{OA}$ & DTX1 & PTX2 & Reference \\
\hline $\begin{array}{c}\text { IFR-DAU- } \\
\text { 03An }\end{array}$ & France & A & + & $<\mathrm{LOD}$ & $<\mathrm{LOD}$ & Present study \\
\hline $\begin{array}{l}\text { IFR-DAU- } \\
\text { 01Es }\end{array}$ & France & A & + & $<\mathrm{LOD}$ & $<\mathrm{LOD}$ & Present study \\
\hline $\begin{array}{l}\text { IFR-DAU- } \\
01 \mathrm{Ca}\end{array}$ & France & A & + & $<\mathrm{LOD}$ & $<\mathrm{LOD}$ & Present study \\
\hline $\begin{array}{l}\text { IFR-DAU- } \\
01 \mathrm{Ke}\end{array}$ & France & A & + & $<\mathrm{LOD}$ & $<$ LOD & Present study \\
\hline $\begin{array}{l}\text { IFR-DAU- } \\
\text { 02Bm }\end{array}$ & France & A & + & $<\mathrm{LOD}$ & $<\mathrm{LOD}$ & Present study \\
\hline $\begin{array}{l}\text { IFR-DAU- } \\
\text { 01Du }\end{array}$ & France & A & + & $<$ LOD & $<\mathrm{LOD}$ & Present study \\
\hline $\begin{array}{c}\text { IFR-DAU- } \\
\text { 01Bo }\end{array}$ & France & A & + & $<\mathrm{LOD}$ & $<\mathrm{LOD}$ & Present study \\
\hline $\begin{array}{l}\text { IFR-DAU- } \\
02 \mathrm{Ar}\end{array}$ & France & A & + & $<\mathrm{LOD}$ & $<\mathrm{LOD}$ & Present study \\
\hline DAEP01 & USA & A & + & + & + & $\begin{array}{l}\text { Tong et al., } \\
2015\end{array}$ \\
\hline DABOF02 & Canada & A & $<\mathrm{LOD}$ & $<\mathrm{LOQ}$ & + & $\begin{array}{l}\text { Tong et al., } \\
2015\end{array}$ \\
\hline DAMV01 & USA & A & + & + & + & $\begin{array}{l}\text { Tong et al., } \\
2015\end{array}$ \\
\hline VGO1132 & Spain & B & + & + & + & $\begin{array}{l}\text { Riobò et al. } \\
2013 \\
\text { Raho et al., } \\
2013\end{array}$ \\
\hline $\begin{array}{l}\text { IFR-DSA- } \\
01 \mathrm{Co}\end{array}$ & France & B & + & $<\mathrm{LOD}$ & + & Present study \\
\hline $\begin{array}{c}\text { IFR-DSA- } \\
01 \mathrm{Lo}\end{array}$ & France & B & + & $<\mathrm{LOD}$ & + & Present study \\
\hline $\begin{array}{c}\text { IFR-DSA- } \\
01 \mathrm{Me}\end{array}$ & France & B & + & $<\mathrm{LOD}$ & + & Present study \\
\hline $\begin{array}{l}\text { IFR-DSA- } \\
01 \mathrm{Lt}\end{array}$ & France & B & + & $<$ LOD & + & Present study \\
\hline $\begin{array}{c}\text { IFR-DSA- } \\
\text { 01Th }\end{array}$ & France & B & + & $<\mathrm{LOD}$ & + & Present study \\
\hline $\begin{array}{l}\text { IFR-DSA- } \\
\text { 02Th }\end{array}$ & France & B & + & $<\mathrm{LOD}$ & + & Present study \\
\hline $\begin{array}{c}\text { IFR-DSA- } \\
\text { 03Th }\end{array}$ & France & B & + & $<$ LOD & + & Present study \\
\hline $\begin{array}{l}\text { IFR-DSA- } \\
01 \mathrm{Vp}\end{array}$ & France & B & + & $<\mathrm{LOD}$ & + & Present study \\
\hline $\begin{array}{c}\text { IFR-DSA- } \\
01 \mathrm{Po}\end{array}$ & France & B & + & $<\mathrm{LOD}$ & + & Present study \\
\hline $\begin{array}{c}\text { IFR-DSA- } \\
01 \mathrm{Ma}\end{array}$ & France & B & + & $<\mathrm{LOD}$ & + & Present study \\
\hline $\begin{array}{l}\text { IFR-DSA- } \\
01 \mathrm{Lj}\end{array}$ & France & B & + & $<\mathrm{LOD}$ & + & Present study \\
\hline
\end{tabular}

strains clustering into subclade B (' $D$. sacculus') showed a more complex profile with PTX2 as the major compound ( $>60 \%$ ) and low proportions of OA (Fig. 3). Additionally, C9-diol ester of OA was detected in seven of the eleven strains analyzed. Except in two strains from the Atlantic Ocean IFR-DSA-01Lo and IFR-DSA-01Me, in which it accounted for about $30 \%$ of the toxin content (Figs. 3 and S1), this compound was present as a minor toxin $(<; 9 \%)$ in the other five strains (Table S2).

\section{Discussion}

\subsection{Molecular identification of strains}

Phylogenetic analyses indicated that molecular data are congruent with morphological features to identify unambiguously four species, i.e. $D$. acuta, D. caudata, D. tripos and D. acuminata-complex. Molecular analyses performed on two genetic markers, ITS-LSU rDNA region and mitochondrial $\operatorname{cox} 1$, produced a rather similar overall topology, but some clades were differently resolved depending on the region analyzed. The present data suggest that $\operatorname{cox} 1$ fails to discriminate species although morphologically easily recognizable, such as $D$. caudata and $D$. tripos, and which are consistently separated by ITS-5.8S region and LSU rDNA sequences. For this reason, ITS and LSU rDNA regions appear generally as better taxonomic markers than cox1, which has already been shown to be poorly informative for the taxonomy of certain dinoflagellates (e.g. Penna et al., 2014).

\section{Case of the D. acuminata-complex}

In the present study, sequences of 19 strains from various geographical origins were acquired and the absence of any divergence within ITS and LSU rRNA regions suggests that they likely belong to the same taxon. This finding is congruent with previous studies showing that LSU rDNA nuclear gene and ITS region did not separate sequences from the $D$. acuminata-complex, whereas other species are resolved (e.g., Guillou et al., 2002; Stern et al., 2014; Wolny et al., 2020; Zhang et al., 2008). Nevertheless, a divergence was found among strains, with a consistent one-base mismatch in $\operatorname{cox} 1$ sequence of the two subclades A and $\mathrm{B}$. The use of the mitochondrial gene $\operatorname{cox} 1$ has been proposed by Raho et al. (2013) who successfully discriminated species of the complex (D. acuminata, D. ovum, D. sacculus) but they based their interpretation on a large divergence of sequence AM931582 (ascribed to D. acuminata) differing by 17 and 15 mismatches with the Galician sequences AM931583 (D. ovum) and KC576782 (D. sacculus), respectively. However, similar to the study by Park et al. (2019), our data confirm that all $\operatorname{cox} 1$ sequences of $D$. acuminata-complex from various locations worldwide are remarkably similar, while none was closely related to the Galician sequence AM931582, suggesting the possibility of sequencing errors in this sequence. Hence, this sequence should not be considered as a reference for $D$. acuminata, and excluding it, the two subclades identified in our phylogenetic analysis inferred from $\operatorname{cox} 1$ gene diverge by 1 base pair only, which is a small divergence to support a distinction at species level. Since this difference was found in a median part of the sequence, it is likely not artefactual nor influenced by the primers. From a functional point of view, this mutation alters the first position of a codon of the subunit of the cytochrome $c$ oxydase I and the 'GTA' found in subclade A is replaced by 'ATA' in the subclade B. This alteration induces a conservative replacement of an amino acid, since valine (subclade A) and isoleucine (subclade B) have similar biochemical properties which does generally not affect the function of proteins.

Interestingly, the two groups of strains (subclades A and B) present a clear regional pattern, and subclade $\mathrm{A}$ was the unique genotype present in the English Channel, both subclades were present in the Atlantic Ocean, while in the Mediterranean area, only strains of subclade B were found. This situation coincides exactly with previous reports showing that natural samples from the English Channel contained only 'Dinophysis acuminata', those of the Atlantic Ocean a mix of ' $D$. acuminata' and 'D. sacculus', or intermediate forms difficult to identify, while no typical 'D. acuminata' has been found from Mediterranean area (Lassus and Bardouil, 1991; Zingone et al., 1998). Hence, based on these data, strains of subclade A can putatively be interpreted as ' $D$. acuminata' while those of subclade B might correspond with ' $D$. sacculus' although the distinction at species-level is highly questionable.

The D. acuminata / D. sacculus taxonomic issue

The difficult interpretation of $D$. sacculus and its complex taxonomy have already been well summarized and discussed by Zingone et al. (1998). They emphasized that the morphological distinction of $D$. acuminata and $D$. sacculus has been problematic not only in early studies (e. g., Pavillard 1905) but also more recently for specimens from the Spanish and French Atlantic coast (Bravo et al., 1995; Lassus and Bardouil, 1991) where both species are present (Zingone et al., 1998). Species identification in the $D$. acuminata-complex has been traditionally based on the outline of cells as a major character, but several authors illustrated the morphological variability of $D$. acuminata in natural populations (Bravo et al., 1995; Lassus and Bardouil, 1991; Zingone et al., 1998). Recently, Park et al. (2019) summarized these variations reported from numerous studies worldwide and established a typology of 4 different forms, ranging from oval to elongate oval and with a more or less symmetric shape, and noticed that depending on the populations, 


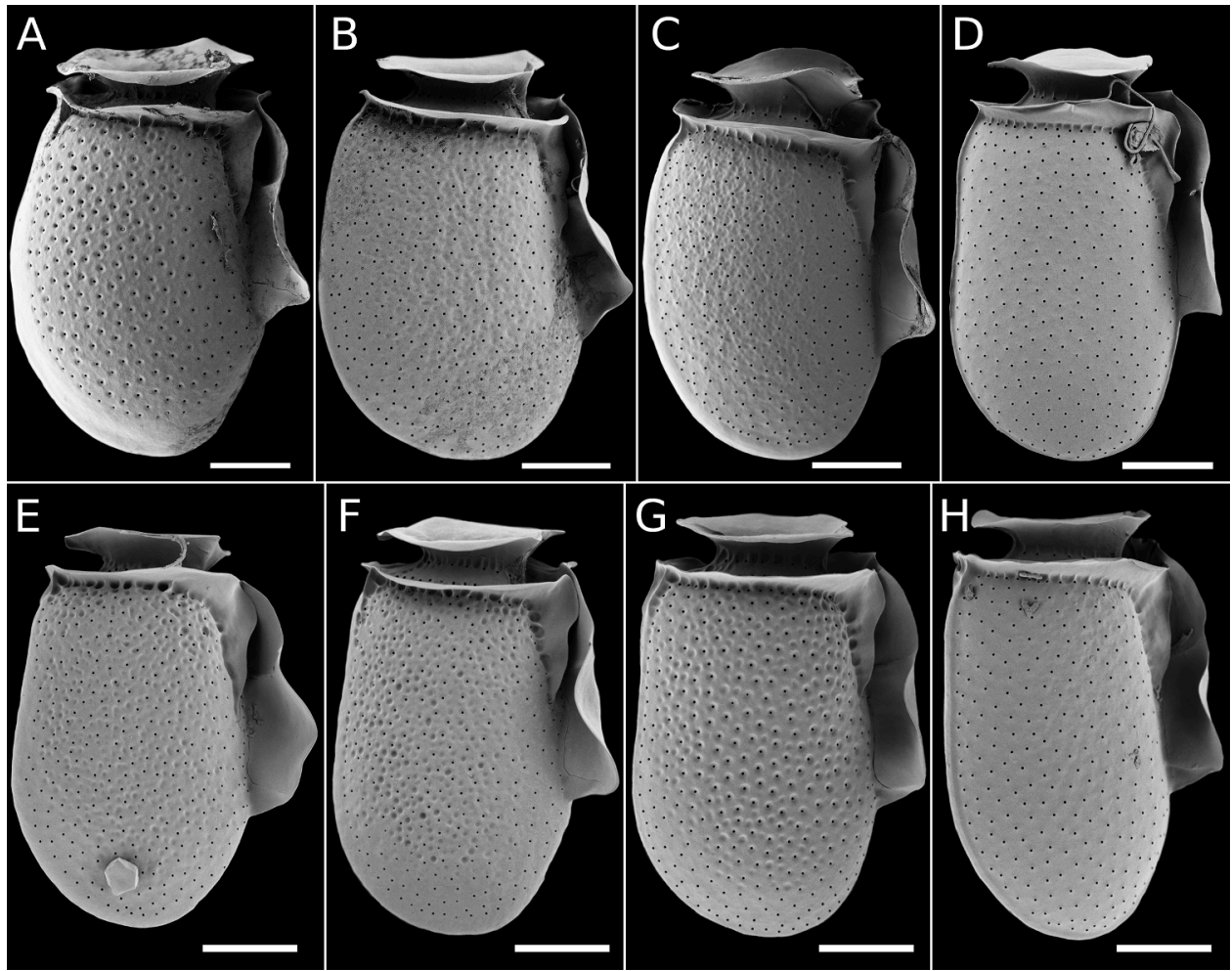

Fig. 6. SEM micrographs of different strains of the D. acuminata-complex (subclade A) from various locations of the English Channel and Atlantic Ocean, showing morphological variability. (A) strain IFR-DAU-03An, (B) strain IFR-DAU-01Es, (C) strain IFR-DAU-01Ca, (D) strain IFR-DAU-01Ke, (E-H) different cells from strain IFR-DAU-02Ar. Scale bars: $10 \mu \mathrm{m}$.

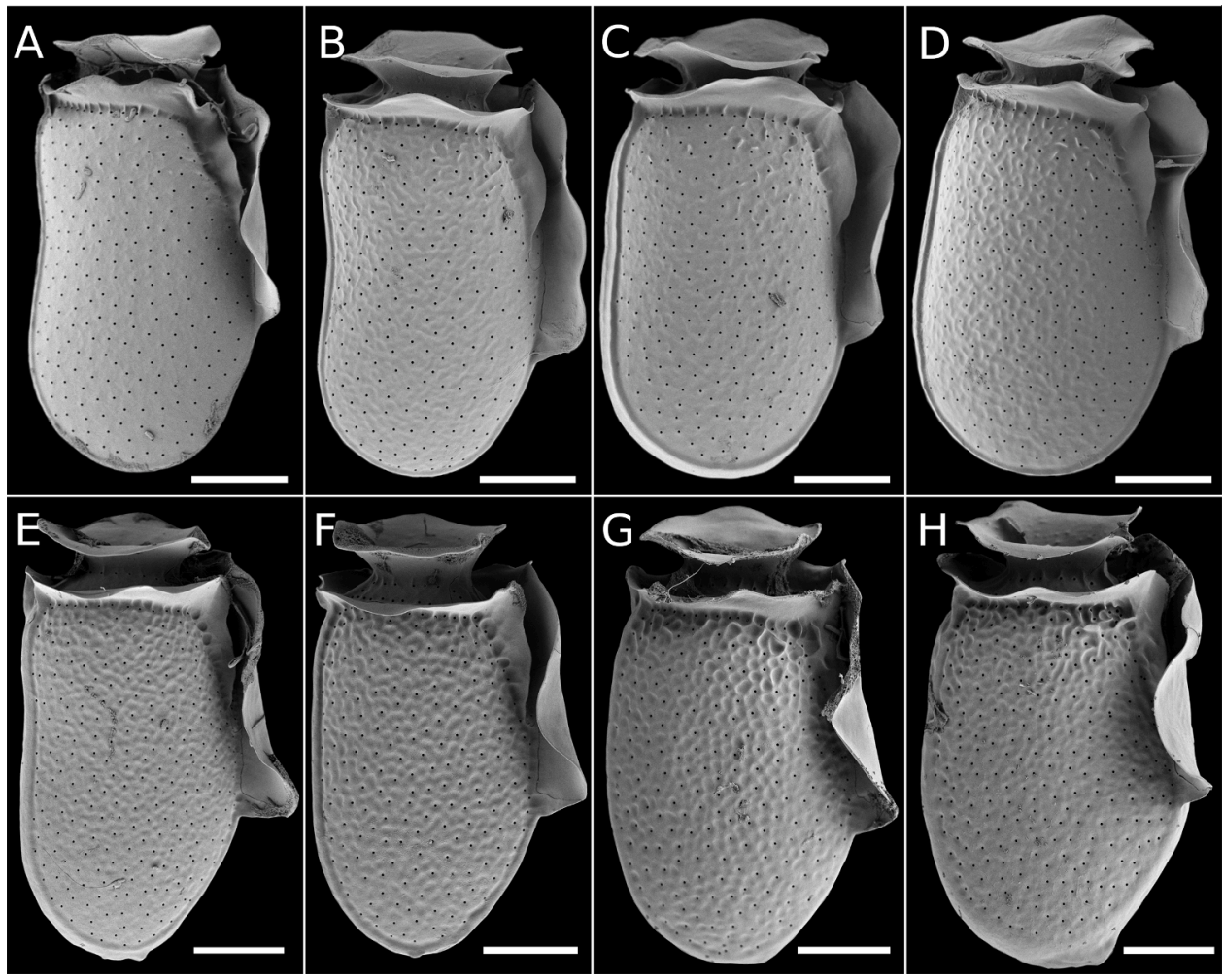

Fig. 7. SEM micrographs of two strains of the D. acuminata-complex (subclade B) from the Atlantic Ocean and Mediterranean Sea, showing morphological variability. (A-D) strain IFR-DSA-01Lt, (E-H) strain IFR-DSA-02Th. Scale bars: $10 \mu \mathrm{m}$. 
the antapex varied from rounded to tapered. According to Park et al. (2019), cells of type A and B have a rounded antapical end, with cells of type $\mathrm{B}$ being longer and more elongated than those of type A. By contrast, cells of type $C$ and D have a more tapered antapical end, with cells of type $\mathrm{C}$ being more oval-shaped than those of type D. In that study, the authors concluded that the problematic $D$. ovum, formerly considered as a separate species from $D$. acuminata might be conspecific and corresponds to a particular morphology (type A, Park et al., 2019). Following this typology, natural samples from French coasts (Berland et al., 1995; Lassus and Bardouil, 1991; Nézan, 2000; Truquet et al., 1996; Zingone et al., 1998) belong to three types, namely type B, which is elongated oval with convex sides and a rounded antapex, type $\mathrm{C}$, which is oval with a convex dorsal margin and more or less straight posterior ventral side, and type $\mathrm{D}$, which is elongated oval with a dorsal posterior side inclined and a ventral posterior side straight, resulting in a tapered antapex (Park et al., 2019). Although Zingone et al. (1998) also emphasized the wide range of variations in natural samples, according to these authors, $D$. sacculus may be distinguishable from $D$. acuminata on the basis of the shape of the hypothecal plates which in $D$. sacculus are generally elongated, almost rectangular or sac-like, whereas in D. acuminata they are shorter, more convex dorsally and often more slender towards the antapex (Zingone et al., 1998). Following this interpretation, cells of the type B by Park et al. (2019) may correspond well to $D$. sacculus while types $C$ and D better fit with $D$. acuminata. Interestingly, (Nézan, 2000) performed a detailed study of natural populations of Dinophysis spp. from French coasts of Brittany (Atlantic Ocean), and she reported the shape of $D$. acuminata to be variable throughout the year, with stocky cells (types C, D) observed at the beginning of spring outbreak, whereas cells then became more elongated (type B) in summer and fall. In contrast with Lassus and Bardouil (1991) who considered the more elongated cells as possible morphotypes of $D$. sacculus, she argued that the slight displacement of the antapex towards the ventral side, giving a slightly oblique apical axis, was a characteristic trait of $D$. acuminata, as suggested by Zingone et al. (1998), and she considered them as summer forms of $D$. acuminata (Nézan, 2000). However, these interpretations of either $D$. acuminata or $D$. sacculus based on wild specimens were impossible to verify in absence of cultured reference material and a molecular/biochemical characterization.

The present study represents a new step in the interpretation of ' $D$. acuminata' and ' $D$. sacculus' by bringing important data from cultured monoclonal strains genetically characterized. In strains of $D$. acuminatacomplex clustering in subclade A in $\operatorname{cox} 1$ phylogeny (i.e. ' $D$. acuminata'), some specimens were found to have the typical stocky shape illustrated by Nézan (2000), such as in IFR-DAU-03An, IFR-DAU-01Es or IFR-DAU-01Ca isolated from English Channel and they correspond well with the morphology of $D$. acuminata. However, this was not always clear, and cells from strains IFR-DAU-01Ke and IFR-DAU-02Ar, genetically identical, were more elongated, and the slight displacement of the antapex towards the ventral side was sometimes completely absent or rarely observed in some specimens within a given strain. Hence, in the subclade A, considerable morphological variations were found to occur in cultures and following the typology by Park et al. (2019), types A, B and $C$ could be found within a single strain. In the subclade B (ascribed as ' $D$. sacculus'), some morphologies were in perfect agreement with the redefinition of $D$. sacculus encompassing $D$. pavillardii (as synonym) by Zingone et al. (1998), but large variations also occurred, and within a given strain, it was possible to observe some specimens with a typical concave dorsal margin co-occurring with cells with a straight or convex margin, with a continuum of shapes and which could be attributed to types A and B from Park et al. (2019). According to the traditional interpretation of morpho-species these specimens could be either interpreted as $D$. sacculus f. reniformis, $D$. sacculus f. sacculus or even $D$. acuminata following the proposal by Zingone et al. (1998). Hence, from the present study, it appears that morphological variations are important within all strains of the $D$. acuminata-complex, and the shape of the dorsal margin should be used cautiously for taxonomic purposes especially to discriminate the problematic species ' $D$. acuminata' and ' $D$. sacculus'. Large morphological variations observed in the cultures suggest that the cell shape might change depending on the physiological and nutritional state of cultured cells. It can be hypothesized that the mixotrophic behavior and kleptoplastidy could modify the overall morphology of cells. Further investigations of morphometric features of different strains at various stages of the feeding process are necessary to confirm this hypothesis in the future. Resolving this issue has important ecological and public health implications and could help to better understand the apparent segregation in space or time of ' $D$. acuminata' and 'D. sacculus', as mentioned by Zingone et al. (1998), or interpret seasonal variations in the morphology of natural populations (Nézan, 2000). Grown under the same experimental conditions the strains of ' $D$. acuminata' and ' $D$. sacculus' isolated from the same geographical area showed very similar growth rate but different to those of the other three species studied, and they were in the range reported in the literature for a Spanish strain of 'D. acuminata' (García-Portela et al., 2018). However, this result needs to be confirmed on a set of strains which have different geographical origins, and under different environmental conditions of salinity and temperature since $D$. sacculus seems to have a higher affinity for semi-enclosed basins and lagoons in contrast to D. acuminata (Zingone et al., 1998).

\subsection{Toxin profiles}

Dinophysis cultures from French coastal waters showed different and species-conserved toxin profiles for each of the three species $D$. acuta, $D$. caudata, D. tripos. However, two different profiles were observed for strains of the D. acuminata-complex. Geographical origin of the strains did not seem to have any influence on toxin composition, and for a given genotype (i.e. within each of ' $D$. acuminata' and ' $D$. sacculus'), the profiles were conserved for strains of various origins. For instance, this is the case for D. acuta which is the only species producing DTX2. This finding is consistent with the original identification of DTX2 in shellfish from Ireland in 1992 (Hu et al., 1992a; Pleasance et al., 1990) where $D$. acuta is frequently found (Fux et al., 2009; McMahon et al., 1999). It should be noted that various studies from around Spain, Portugal and Scotland associated the presence of $D$. acuta with DTX2 in both field-sampled cells and cultures of D. acuta (Fernández et al., 2006; García-Portela et al., 2018; Swan et al., 2018; Vale and Sampayo, 2000), while DTX2 was not detected in D. acuta from New Zealand (MacKenzie et al., 2005).

The two species $D$. caudata and $D$. tripos differed from other Dinophysis species by exhibiting a profile with PTX2 as the sole toxin detected above LOD. The high amounts of PTX2 found in the present study are in accordance with those reported in cultured strains from Spain and Japan (Basti et al., 2015; Rodríguez et al., 2012). Nevertheless, besides an extraordinary high cellular PTX2 content, a trace amount of DTX1 in D. tripos was also observed in a clonal culture from Inokushi Bay (Nagai et al., 2013).

The investigation of 19 strains of the $D$. acuminata-complex allowed us to compare the toxin profiles of the two subclades ' $D$. acuminata' and ' $D$. sacculus' grown under the same experimental conditions. The cultures of ' $D$. acuminata', from either English Channel or Atlantic Ocean always presented a simple toxin profile with only OA detected. While the cultures of ' $D$. sacculus' from Atlantic Ocean and Mediterranean Sea showed a more complex profile comprising PTX2 as the major compound and also containing OA and C9-diol OA. Interestingly, the toxin profiles, in terms of type of compounds, of the ' $D$. sacculus' strains isolated from the Atlantic Ocean did not differ from those from the Mediterranean lagoons. Although variations in the relative proportion of compounds among the strains of ' $D$. sacculus' were detected, the toxin profile always included PTX2 as the major toxin and other components, in contrast to the simple profile observed in ' $D$. acuminata' in this study.

In addition, several studies conducted in Galicia (northwestern Spain) have shown the same difference in the toxin profile between 
' $D$. sacculus' and ' $D$. acuminata'. The strains of ' $D$. acuminata' contained only AO (García-Portela et al., 2018; Hernandez-Urcera et al., 2018), while those of ' $D$. sacculus' showed a toxic profile dominated by PTX2 with moderate amounts of AO and traces of DTX1 (Riobó et al., 2013).

While toxin composition could appear as a reliable feature separating ' $D$. acuminata' from ' $D$. sacculus' at least in French and Spanish coastal waters, this specificity of toxin profiles observed within the $D$. acuminata-complex does not seem to be consistent with observations at a broader geographical scale. For instance, strains of 'Dinophysis acuminata', DAEP01, DABOF02 and DAMV01, isolated from three sites within the northeastern US/Canada coastal region in the Atlantic Ocean are genetically identical with the French strains of ' $D$. acuminata' (subclade A, Fig. 4) but they produced PTX2 as the major compound and only low amounts of OA and/or DTX1 (Table 4, Raho et al., 2013; Riobó et al., 2013; Tong et al., 2015), which corresponds to the profile observed in 'D. sacculus' (subclade B) in the present study. Moreover, PTX2 was reported to be the sole toxin detected in seven cultivated strains of $D$. acuminata from Denmark (Nielsen et al., 2012), but unfortunately no molecular data are available for more comparisons. Furthermore, numerous studies have reported a toxin profile dominated by PTX2 in $D$. acuminata from Norway, which is the type locality of this species, while in New Zealand, Japan, China, Chile, Argentina and North America $D$. acuminata also contained smaller amounts of OA and/or DTX1 (Basti et al., 2018; Fabro et al., 2016; Fux et al., 2011; Gao et al., 2019; Hackett et al., 2009; Hattenrath-Lehmann et al., 2015; Kamiyama and Suzuki, 2009; MacKenzie et al., 2005; Miles et al., 2004b; Suzuki et al., 2009; Tong et al., 2015; Uchida et al., 2018). Similarly, LC-MS analysis of picked cells of $D$. acuminata from northern Chile, solely showed high levels of PTX2 (Blanco et al., 2007). Hence, these data appear conflicting and it is not yet clear whether the toxin profile can potentially be used as a chemotaxonomic indicator related with genetics to separate species/ecotypes or not.

The production of C9-diol esters of OA was solely detected in $D$. sacculus in the present study, while $D$. acuta did not produce any such diol-esters above LOD. This finding is in contrast to previous study in our laboratory where a Spanish strain of D. acuta produced also a C9-diol ester (Sibat et al., 2018). Diol-esters of OA and DTX1 had originally been identified in cultures of Prorocentrum lima (Hu et al., 1992b). It is still a matter of debate whether dinoflagellates produce OA and its analogues DTX1 and -2 de novo and store these metabolites as such in the cell or whether more complex derivatives such as diol esters or sulfated diol-esters of $\mathrm{OA}$ and its analogues are initially biosynthesized and subsequently transformed during transport inside the cell and during excretion. Thus, further investigations of the toxin production of genetically well-characterized clonal strains from various origins are necessary to clarify that the toxin profile does not change throughout the life-cycle and is not influenced by physiology, growth stage or external factors.

The toxin profiles produced by the species or ecotypes also have direct relevance to public health. Various risk assessments of algal metabolites accumulating in shellfish, including latest evidence examined from the New Zealand experience (Boundy et al., 2020), suggest that PTXs pose little or no risk to consumer safety (Lawrence et al., 2011). Nevertheless, D. sacculus, even though the main toxin produced is PTX2, also produces OA and esters of OA and must therefore still be considered important in public health-orientated monitoring programs. Furthermore, recent evidence suggests that PTXs may have an impact on oyster recruitment (Gaillard et al., 2020), and therefore all Dinophysis species should be re-examined for their production of PTXs and their potential implication in shellfish mortalities.

\section{Conclusion}

Despite a regular monitoring of Dinophysis species in French coastal waters and presence of DSTs in shellfish, it is still difficult to ascertain the contribution of each species to shellfish contamination because of morphological variability and difficult taxonomic identification (Reguera et al., 2012). For the first time in France, the present study based on the analysis of 30 clonal strains from various sites from English Channel, Atlantic Ocean and the Mediterranean area revealed four species identified unambiguously by morphology, molecular data and their toxin content. Although some recurrent species have not yet been successfully isolated such as $D$. fortii, this constitutes the major part of toxic Dinophysis spp. found in French coastal waters.

For a long time, the identification of the most common and closely related species $D$. acuminata and $D$. sacculus has been highly problematic in natural samples, which has led several authors to consider them as $D$. acuminata-complex (Bravo et al., 1995; Lassus and Bardouil, 1991). Data acquired from 19 strains in the present study fail to clearly separate them as two distinct species, but one base-difference in the cox1 gene was consistent to separate ' $D$. acuminata' and ' $D$. sacculus', and the toxin content associated was shown to differ among them. Whether they actually represent two separate species or ecotypes (varieties) of a same species cannot be resolved from our data. Molecular data do not support a separation at the species-level, considering that ITS-5.8S and LSU rDNA are generally good taxonomic markers for dinoflagellates. Furthermore, the considerable morphological variability observed in cultured strains seem to indicate that cell morphology shows high plasticity and may change in natural populations due to the environmental conditions, which confirms the observations of variable morphologies in natural samples by Lassus and Bardouil (1991). The existence of two distinct toxin profiles in the strains studied could appear as a reliable feature to separate strains, but conflicting data from the literature and lack of information for well characterized strains prevent the use of this character for taxonomic purpose.

The molecular data presented here agree with the previous study by Park et al. (2019) in that $D$. sacculus may be considered to be similar to $D$. ovum and they could represent particular morphotypes of D. acuminata. On the other hand, our data from $\operatorname{cox} 1$ gene and toxin profiles suggest a slight divergence of these organisms which is relevant from an ecological point of view: $D$. sacculus has a higher affinity for semi-enclosed basins and lagoons than $D$. acuminata (Zingone et al., 1998). It can be hypothesized that they are not yet genetically divergent enough to be considered as separate species, and they may be ecotypes in an early stage of speciation process (Le Gac et al., 2016). Resolving this species concept issue will not be an easy task, but clonal strains will allow further studies including cross-mating experiments, genetic analyses based on multigene, transcriptomic or even genomic approaches and in-depth analyses of toxin production which will indisputably help to better understand the level of genetic divergence in ' $D$. acuminata' and 'D. sacculus'.

Independent of the taxonomic issue, the toxin profiles of the two ecotypes are significantly different in terms of public health impact since PTXs, the major toxins produced by the ecotype ' $D$. sacculus', are considered of much lower risk to public health due to their rapid biotransformation in mussels and instability in conditions of the human digestive system. Additionally, the difference in toxin profiles within the 'D. acuminata' complex but also for other species should prompt us to explore their respective environmental impact and in particular their effect on the recruitment of bivalve molluscs and other marine organisms.

\section{Authors contributions}

VS and NC designed and supervised the study, drafted the paper and coordinated its revisions. Moreover, VS also coordinated and contributed to establishing and maintaining Dinophysis clonal cultures, while NC also performed the microscopic observation and phylogenetic analyses. GB conducted the molecular analysis and sequencing and contributed to drafting and editing the paper. MS and GAR conducted the LC-MS analysis and contributed to drafting and editing the paper. LC performed cells measurements, contributed to establishing and 
maintaining Dinophysis clonal cultures, and to drafting and editing the paper. MPR contributed to the field sampling and editing the paper. VR and FM contributed to establishing and maintaining Dinophysis clonal cultures. PH obtained external funding of the study. PH and SG participated in writing and editing the paper.

\section{Declaration of Competing Interest}

The authors declare that they have no known competing financial interests or personal relationships that could have appeared to influence the work reported in this paper.

\section{Acknowledgments}

We thank our colleagues from the Ifremer coastal laboratories for tracking and sampling Dinophysis spp: S. Françoise (LER Normandie), A. Doner, A. Duval, A. Terre-Terrillon (LER Bretagne Occidentale), K. Colin, M. Fortune, M. Rétho and A. Schmitt (LER Morbihan Pays de Loire), C.Meteigner (LER Arcachon), E. Abadie and C. Hubert (LER Languedoc Roussillon), F. Marco-Mirales and C. Connes (LER Provence Côte d'Azur). We also thank A. Derrien (LER Bretagne Occidentale) for tracking down DSP toxins monitoring data. We are grateful to Dr. David Jaén (LCCRRPP,Junta de Andalucía, Spain) for generously sharing his cultures of Teleaulax amphioxeia (AND-A0710) and Dr. Per Juel Hansen (Marine Biological Section, University of Copenhagen, Helsingør, Denmark) for his strain of Mesodinium rubrum (MrDK-2009). We also thanks Drs. Satoshi Nagai and Takeshi Kamiyama (National Reasearch Institute of Fisheries and Environment of Inland Sea, Hiroshima, Japan), Dr. Beatriz Reguera and Pilar Rial (Instituto Espaňol de Oceanographia, Vigo, Spain) for their invaluable advices on Dinophysis culturing. We extend special thanks to Elisabeth Nézan and Dr. Patrick Lassus who kindly accepted to read and improve the manuscript. This work was funded by the project CoCliME which is part of ERA4CS, an ERA-NET initiated by JPI Climate, and funded by EPA (IE), ANR (FR), BMBF (DE), UEFISCDI (RO), RCN (NO), and FORMAS (SE), with co-funding by the European Union (Grant 690462).

\section{Supplementary materials}

Supplementary material associated with this article can be found, in the online version, at doi:10.1016/j.hal.2021.101974.

\section{References}

Adam, R.D., Ortega, Y.R., Gilman, R.H., Sterling, C.R., 2000. Intervening transcribed spacer region 1 variability in Cyclospora cayetanensis. J. Clin Microbiol. 38, 2339-2343.

Alzieu, C., Lassus, P., Maggi, P., Poggi, R., Ravoux, G., 1983. Contamination Des Coquillages Des Côtes Bretonnes Et Normandes Par Une Algue Unicellulaire Toxique (Dinophysis acuminata).Rapp. Tech. No. 4. ISTPM. Institut Scientifique et Technique des Pêches Maritimes, Nantes, France, p. 33.

Amzil, Z., Sibat, M., Royer, F., Masson, N., Abadie, E., 2007. Report on the first detection of pectenotoxin-2, spirolide-A and their derivatives in French shellfish. Mar. Drugs 5 (4), 168-179.

Basti, L., Suzuki, T., Uchida, H., Kamiyama, T., Nagai, S., 2018. Thermal acclimation affects growth and lipophilic toxin production in a strain of cosmopolitan harmful alga Dinophysis acuminata. Harmful Algae 73, 119-128. https://doi.org/10.1016/j. hal.2018.02.004.

Basti, L., Uchida, H., Matsushima, R., Watanabe, R., Suzuki, T., Yamatogi, T., Nagai, S., 2015. Influence of temperature on growth and production of pectenotoxin-2 by a monoclonal culture of Dinophysis caudata. Mar. Drugs 13 (12), 7124-7137. https:// doi.org/10.3390/md13127061.

Batifoulier, F., Lazure, P., Velo-Suarez, L., Maurer, D., Bonneton, P., Charria, G., Dupuy, C., Gentien, P., 2013. Distribution of Dinophysis species in the Bay of Biscay and possible transport pathways to Arcachon Bay. J. Mar. Syst. 109, S273-S283.

Belin, C., Soudant, D., 2018. Trente années d'observation des microalgues et des toxines d'algues sur le littoral. Editions QUAE, $261 \mathrm{pp}$.

Belin, C., Soudant, D., Amzil, Z., 2020. Three decades of data on phytoplankton and phycotoxins on the French coast: lessons from REPHY and REPHYTOX. Harmful Algae, 101733. https://doi.org/10.1016/j.hal.2019.101733.
Berland, B.R., Maestrini, S.Y., Grzebyk, D., 1995. Observations on possible life cycle stages of the dinoflagellate Dinophysis cf. acuminata, Dinophysis acuta and Dinophysis pavillardi. Aquat. Microb. Biol. 9, 183-189.

Blanco, J., Alvarez, G., Uribe, E., 2007. Identification of pectenotoxins in plankton, filter feeders, and isolated cells of a Dinophysis acuminata with an atypical toxin profile, from Chile. Toxicon 49 (5), 710-716.

Boundy, M.J., Harwood, D.T., Kiermeier, A., McLeod, C., 2020. Pectenotoxins and Okadaic acid group toxins in New Zealand bivalve molluscan shellfish, 2009-2019: Risk Assessment Prepared for the Ministry for Primary Industries, Cawthron ed., p. 89.

Bravo, I., Delgado, M., Fraga, S., Honsell, G., Lassus, P., Montresor, M., Sampayo, M., 1995. The Dinophysis genus: toxicity and species definition in Europe. In: Lassus, P., Arzul, G., Erard, E., Gentien, P., Marcaillou, C. (Eds.), Harmful Marine Algal Blooms. Lavoisier, Paris, pp. 843-845.

Chomérat, N., Bilien, G., Derrien, A., Henry, K., Ung, A., Viallon, J., Darius, H.T., Mahana Iti Gatti, C., Roue, M., Herve, F., Reveillon, D., Amzil, Z., Chinain, M., 2019. Ostreopsis lenticularis Y. Fukuyo (Dinophyceae, Gonyaulacales) from French Polynesia (South Pacific Ocean): a revisit of its morphology, molecular phylogeny and toxicity. Harmful Algae 84, 95-111. https://doi.org/10.1016/j. hal.2019.02.004.

Darriba, D., Taboada, G.L., Doallo, R., Posada, D., 2012. jModelTest 2: more models, new heuristics and parallel computing. Nat. Methods 9, 772.

Delmas, D., Herbland, A., Maestrini, S.Y., 1993. Do Dinophysis spp. come from the "open sea" along the French Atlantic coast? In: Smayda, T.J., Shimizu, Y. (Eds.), Toxic Phytoplankton Blooms in the Sea. Elsevier, New York, pp. 489-494.

Edvardsen, B., Shalchian-Tabrizi, K., Jakobsen, K.S., Medlin, L.K., Dahl, E., Brubak, S. Paasche, E., 2003. Genetic variability and molecular phylogeny of Dinophysis species (Dinophyceae) from Norwegian waters inferred from single cell analyses of rDNA. J. Phycol. 39 (2), 395-408.

Fabro, E., Almandoz, G.O., Ferrario, M., Tillmann, U., Cembella, A., Krock, B., 2016. Distribution of Dinophysis species and their association with lipophilic phycotoxins in plankton from the Argentine Sea. Harmful Algae 59, 31-41. https://doi.org/ 10.1016/j.hal.2016.09.001.

Fernández, M.L., Reguera, B., González-Gil, S., Míguez, A., 2006. Pectenotoxin-2 in single-cell isolates of Dinophysis caudata and Dinophysis acuta from the Galician Rías (NW Spain). Toxicon 48 (5), 477-490. https://doi.org/10.1016/j. toxicon.2006.05.016.

Fux, E., Biré, R., Hess, P., 2009. Comparative accumulation and composition of lipophilic marine biotoxins in passive samplers and in mussels (M. edulis) on the West Coast of Ireland. Harmful Algae 8 (3), 523-537.

Fux, E., Smith, J.L., Tong, M.M., Guzman, L., Anderson, D.M., 2011. Toxin profiles of five geographical isolates of Dinophysis spp. from North and South America. Toxicon 57 (2), 275-287.

Gaillard, S., Le Goïc, N., Malo, F., Boulais, M., Fabioux, C., Zaccagnini, L., Carpentier, L., Sibat, M., Réveillon, D., Séchet, V., Hess, P., Hégaret, H., 2020. Cultures of Dinophysis sacculus, D. acuminata and pectenotoxin 2 affect gametes and fertilization success of the Pacific oyster, Crassostrea gigas. Environ. Pollut. 265, 114840 https://doi.org/ 10.1016/j.envpol.2020.114840.

Gao, H., Tong, M., An, X., Smith, J.L., 2019. Prey lysate enhances growth and toxin production in an isolate of Dinophysis acuminata. Toxins Basel 11 (1).

García-Portela, M., Reguera, B., Sibat, M., Altenburger, A., Rodríguez, F., Hess, P., 2018. Metabolomic profiles of Dinophysis acuminata and Dinophysis acuta using nontargeted high-resolution mass spectrometry: effect of nutritional status and prey. Mar. Drugs 16 (5), 143. https://doi.org/10.3390/md16050143.

Gentien, P., Lunven, M., Lehaitre, M., Duvent, J.L., 1995. In situ depth profiling of particle sizes. Deep Sea Res. 42 (8), 1297-1312.

Guillard, R.L., 1973. Division rates. In: Stein, J. (Ed.), Handbook of Phycological Methods. Cambridge University Press, London, pp. 289-312.

Guillard, R.R.L., Hargraves, P.E., 1993. Stichochrysis immobilis is a diatom, not a chrysophyte. Phycologia 32 (3), 234-236.

Guillou, L., Nézan, E., Cueff, V., Erard-Le Denn, E., Cambon-Bonavita, M.-.A., Gentien, P., Barbier, G., 2002. Genetic diversity and molecular detection of three toxic dinoflagellate genera (Alexandrium, Dinophysis, and Karenia) from French coasts. Protist 153 (3), 223.

Guindon, S., Dufayard, J.F., Lefort, V., Anisimova, M., Hordijk, W., Gascuel, O., 2010 New algorithms and methods to estimate maximum-likelihood phylogenies: assessing the performance of PhyML 3.0. Syst Biol 59.

Guiry, M.D., 2020. In: Guiry, M.D., Guiry, G.M. (Eds.). National University of Ireland, Galway. World-wide electronic publication. http://www.algaebase.org. searched on 28 February 2020.

Hackett, J.D., Tong, M., Kulis, D.M., Fux, E., Hess, P., Biré, R., Anderson, D.M., 2009. DSP toxin production de novo in cultures of Dinophysis acuminata (Dinophyceae) from North America. Harmful Algae 8 (6), 873-879.

Hallegraeff, G.M., Lucas, I.A.N., 1988. The marine dinoflagellate genus Dinophysis (Dinophyceae): photosynthetic, neritic and non-photosynthetic, oceanic species. Phycologia 27, 25-42.

Hattenrath-Lehmann, T.K., Marcoval, M.A., Mittlesdorf, H., Goleski, J.A., Wang, Z., Haynes, B., Morton, S.L., Gobler, C.J., 2015. Nitrogenous Nutrients Promote the Growth and Toxicity of Dinophysis acuminata during Estuarine Bloom Events. PLoS ONE 10 (4), e0124148. https://doi.org/10.1371/journal.pone.0124148.

Hernandez-Urcera, J., Rial, P., Garcia-Portela, M., Loures, P., Kilcoyne, J., Rodríguez, F., Fernandez-Villamarin, A., Reguera, B., 2018. Notes on the cultivation of two mixotrophic Dinophysis species and their ciliate prey Mesodinium rubrum. Toxins Basel 10 (12), 505. https://doi.org/10.3390/toxins10120505. 
Hu, T., Doyle, J., Jackson, D., Marr, J., Nixon, E., Pleasance, S., Quilliam, M.A., Walter, J. A., Wright, J.L.C., 1992a. Isolation of a new diarrhetic shellfish poison from Irish mussels. J. Chem. Soc. Ser. (1), 39-41.

Hu, T., Marr, J., DeFreitas, A.S.W., Quilliam, M.A., Walter, J.A., Wright, J.L.C., Pleasance, S., 1992b. New diol esters isolated from cultures of the dinoflagellates Prorocentrum lima and Prorocentrum concavum. J. Nat. Prod. 55 (11), 1631-1637.

Kamiyama, T., Suzuki, T., 2009. Production of dinophysistoxin-1 and pectenotoxin-2 by a culture of Dinophysis acuminata (Dinophyceae). Harmful Algae 8 (2), 312-317.

Kumagai, M., Yanagi, T., Murata, M., Yasumoto, T., Kat, M., Lassus, P., RodríguezVazquez, J.A., 1986. Okadaic acid as the causative toxin of diarrhetic shellfish poisoning in Europe. Agric. Biol. Chem. 50, 2853-2857.

Kumar, S., Stecher, G., Li, M., Knyaz, C., Tamura, K., 2018. MEGA X: molecular evolutionary genetics analysis across computing platforms. Mol. Biol. Evol. 35, 1547-1549. https://doi.org/10.1093/molbev/msy096.

Lassus, P., Bardouil, M., 1991. Le complexe Dinophysis acuminata: identification des espèces le long des côtes françaises. Cryptogam. Algol. 12 (1), 1-9.

Lassus, P., Bardouil, M., Berthom, J.-.P., Maggi, P., Truquet, P., Le Dean, L., 1988. Seasonal occurrence of Dinophysis sp. along the French coast between 1983 and 1987. Aquat. Living Resour. 1, 155-164.

Lassus, P., Bardouil, M., Truquet, I., Truquet, P., le Baut, C., Pierri, M.J., 1985. Dinophysis acuminata distribution and toxicity along the southern Brittany coast (France): correlation with hydrological parameters. In: Anderson, D.M., White, A.W., Baden, D.G. (Eds.), Toxic Dinoflagellates. Elsevier, New York, pp. 159-164.

Lawrence, J., Loreal, H., Toyofuku, H., Hess, P., Iddya, K., Ababouch, L., 2011. Assessment and management of biotoxin risks in bivalve molluscs. FAO Fish. Aquacult. 337. Technical Paper No. 551.

Le Gac, M., Metegnier, G., Chomérat, N., Malestroit, P., Quere, J., Bouchez, O., Siano, R., Destombe, C., Guillou, L., Chapelle, A., 2016. Evolutionary processes and cellular functions underlying divergence in Alexandrium minutum. Mol. Ecol. 25 (20), 5129-5143. https://doi.org/10.17882/45445.

Lin, S.J., Zhang, H.A., Spencer, D.F., Norman, J.E., Gray, M.W., 2002. Widespread and extensive editing of mitochondrial mRNAS in dinoflagellates. J. Mol. Biol. 320 (4), 727-739. https://doi.org/10.1016/s0022-2836(02)00468-0.

MacKenzie, L., Beuzenberg, V., Holland, P., McNabb, P., Suzuki, T., Selwood, A., 2005 Pectenotoxin and okadaic acid-based toxin profiles in Dinophysis acuta and Dinophysis acuminata from New Zealand. Harmful Algae 4 (1), 75-85.

Maestrini, S.Y., 1998. Bloom dynamics and ecophysiology of Dinophysis spp. NATO ASI Ser. G 41, 242-265.

Maestrini, S.Y., Berland, B.R., Grzebyk, D., Spano, A.M., 1995. Dinophysis spp. cells concentrated from nature for experimental purposes, using size fractionation and reverse migration. Aquat. Microb. Ecol. 9 (2), 177-182.

Marcaillou-Le Baut, C., Masselin, P., 1989. Recent data on diarrhetic shellfish poisoning in France. In: Granéli, E, Sundström, B, Edler, L, Anderson, DM (Eds.), Toxic Marine Phytoplankton. Elsevier, New-York, pp. 487-492.

Marin, I., Aguilera, A., Reguera, B., Abad, J.P., 2001. Preparation of DNA suitable for PCR amplification from fresh or fixed single dinoflagellate cells. BioTech. 30 (1), 88

McMahon, T., Silke, J., Cahill, B., 1999. Irish coastal dinoflagellate blooms and shellfish toxicity. J. Shellfish Res. 18 (2), 722-723.

Miles, C.O., Wilkins, A.L., Munday, R., Dines, M.H., Hawkes, A.D., Briggs, L.R., Sandvik, M., Jensen, D.J., Cooney, J.M., Holland, P.T., Quilliam, M.A., Lincoln MacKenzie, A., Beuzenberg, V., Towers, N.R., 2004a. Isolation of pectenotoxin-2 from Dinophysis acuta and its conversion to pectenotoxin-2 seco acid, and preliminary assessment of their acute toxicities. Toxicon 43 (1), 1-9.

Miles, C.O., Wilkins, A.L., Samdal, I.A., Sandvik, M., Petersen, D., Quilliam, M.A., Naustvoll, L.J., Rundberget, T., Torgersen, T., Hovgaard, P., Jensen, D.J., Cooney, J. M., 2004b. A novel pectenotoxin, PTX-12, in Dinophysis spp. and shellfish from Norway. Chem. Res. Toxicol. 17 (11), 1423-1433.

Nagai, S., Suzuki, T., Kamiyama, T., 2013. Successful cultivation of the toxic dinoflagellate Dinophysis tripos (Dinophyceae). Plankton Benthos Res. 8 (4), 171-177.

Nézan, E., 2000. Episodes à Dinophysis dans le Finistère et variations morphologiques des espèces responsables. R.S.T - DEL/00-01/Concarneau, p. 31. https://archimer.ifreme r.fr/doc/00037/14847/.

Nielsen, L.T., Krock, B., Hansen, P.J., 2012. Effects of light and food availability on toxin production, growth and photosynthesis in Dinophysis acuminata. Mar. Ecol. Progr. Ser. 471, 37-50.

Nunn, G.B., Theisen, B.F., Christensen, B., Arctander, P., 1996. Simplicity-correlated size growth of the nuclear 28S ribosomal RNA D3 expansion segment in the crustacean order Isopoda. J. Mol. Evol. 42, 211-223.

Park, J.H., Kim, M., Jeong, H.J., Park, M.G., 2019. Revisiting the taxonomy of the "Dinophysis acuminata complex'" (Dinophyta)'. Harmful Algae 88, 101657. https:// doi.org/10.1016/j.hal.2019.101657.

Park, M.G., Kim, S., Kim, H.S., Myung, G., Kang, Y.G., Yih, W., 2006. First successful culture of the marine dinoflagellate Dinophysis acuminata. Aquat. Microb. Ecol. 45 (2), 101-106.

Pavillard, J., 1905. Recherches sur la flore pélagique (phytoplancton) de l'etang de thau. Montpellier, p. 116.

Penna, A., Battocchi, C., Capellacci, S., Fraga, S., Aligizaki, K., Lemée, R., Vernesi, C., 2014. Mitochondrial, but not rDNA, genes fail to discriminate dinoflagellate species in the genus Ostreopsis. Harmful Algae 40, 40-50.

Penna, A., Magnani, M., 1999. Identification of Alexandrium (Dinophyceae) species using PCR and rDNA-targeted probes. J. Phycol. 35 (3), 615-621.
Pleasance, S., Quilliam, M.A., de Freitas, A.S.W., Marr, J.C., Cembella, A.D., 1990. Ionspray mass spectrometry of marine toxins. II. Analysis of diarrhetic shellfish toxins in plankton by liquid chromatography/mass spectrometry. Rapid Commun. Mass Spectrom. 4, 206-213.

Raho, N., Pizarro, G., Escalera, L., Reguera, B., Marín, I., 2008. Morphology, toxin composition and molecular analysis of Dinophysis ovum Schütt, a dinoflagellate of the "Dinophysis acuminata complex. Harmful Algae 7 (6), 839-848. https://doi.org/ 10.1016/j.hal.2008.04.006.

Raho, N., Rodríguez, F., Reguera, B., Marín, I., 2013. Are the mitochondrial cox1 and cob genes suitable markers for species of Dinophysis Ehrenberg? Harmful Algae 28, 64-70.

Reguera, B., Riobó, P., Rodríguez, F., Díaz, P.A., Pizarro, G., Paz, B., Franco, J.M., Blanco, J., 2014. Dinophysis toxins: causative organisms, distribution and fate in shellfish. Mar. Drugs 12 (1), 394-461.

Reguera, B., Velo-Suárez, L., Raine, R., Park, M.G., 2012. Harmful Dinophysis species: a review. Harmful Algae 14, 87-106. https://doi.org/10.1016/j.hal.2011.10.016.

Riobó, P., Reguera, B., Franco, J.M., Rodríguez, F., 2013. First report of the toxin profile of Dinophysis sacculus Stein from LC-MS analysis of laboratory cultures. Toxicon 76 (0), 221-224.

Rodríguez, F., Escalera, L., Reguera, B., Rial, P., Riobo, P., da Silva, T.D., 2012. Morphological variability, toxinology and genetics of the dinoflagellate Dinophysis tripos (Dinophysiaceae, Dinophysiales). Harmful Algae 13, 26-33.

Ronquist, F., Huelsenbeck, J.P., 2003. MrBayes 3: bayesian phylogenetic inference under mixed models. Bioinformatics 19, 1572-1574.

Sanagi, M.M., Ling, S.L., Nasir, Z., Hermawan, D., Ibrahim, W.A., Abu Naim, A., 2009. Comparison of signal-to-noise, blank determination, and linear regression methods for the estimation of detection and quantification limits for volatile organic compounds by gas chromatography. J. AOAC Int. 92 (6), 1833-1838.

Scholin, C.A., Anderson, D.M., 1996. LSU rDNA-based RFLP assays for discriminating species and strains of Alexandrium (Dinophyceae). J. Phycol. 32 (6), 1022-1035.

Scholin, C.A., Herzog, M., Sogin, M., Anderson, D.M., 1994. Identification of group- and strain-specific genetic markers for globally distributed Alexandrium (Dinophyceae). 2. Sequence analysis of a fragment of the LSU rRNA gene. J. Phycol. 30 (6), 999-1011.

Sibat, M., Garcia-Portela, M., Hess, P., 2018. First identification of a C9-diol-ester of okadaic acid in Dinophysis acuta from Galician Rias Baixas (NW Spain). Toxicon 153, 19-22. https://doi.org/10.1016/j.toxicon.2018.08.005.

Stern, R.F., Amorim, A.L., Bresnan, E., 2014. Diversity and plastid types in Dinophysis acuminata complex (Dinophyceae) in Scottish waters. Harmful Algae 39, 223-231.

Suzuki, T., Miyazono, A., Baba, K., Sugawara, R., Kamiyama, T., 2009. LC-MS/MS analysis of okadaic acid analogues and other lipophilic toxins in single-cell isolates of several Dinophysis species collected in Hokkaido, Japan. Harmful Algae 8 (2), 233-238.

Swan, S.C., Turner, A.D., Bresnan, E., Whyte, C., Paterson, R.F., McNeill, S., Mitchell, E., Davidson, K., 2018. Dinophysis acuta in Scottish Coastal Waters and Its Influence on Diarrhetic Shellfish Toxin Profiles. Toxins Basel 10 (10).

Tong, M., Smith, J.L., Richlen, M., Steidinger, K.A., Kulis, D.M., Fux, E., Anderson, D.M., 2015. Characterization and comparison of toxin-producing isolates of Dinophysis acuminata from New England and Canada. J. Phycol. 51 (1), 66-81.

Truquet, P., Lassus, P., Honsell, G., LeDean, L., 1996. Application of a digital pattern recognition system to Dinophysis acuminata and D-sacculus complexes. Aquat. Living Resour. 9 (3), 273-279.

Uchida, H., Watanabe, R., Matsushima, R., Oikawa, H., Nagai, S., Kamiyama, T., Baba, K., Miyazono, A., Kosaka, Y., Kaga, S., Matsuyama, Y., Suzuki, T., 2018. Toxin profiles of okadaic acid analogues and other lipophilic toxins in Dinophysis from Japanese coastal waters. Toxins Basel 10 (11), 457. https://doi.org/10.3390/ toxins 10110457.

Vale, P., Sampayo, M.A.D., 2000. Dinophysistoxin-2: a rare diarrhoeic toxin associated with Dinophysis acuta. Toxicon 38 (11), 1599-1606.

Vial, J., Jardy, A., 1999. Experimental comparison of the different approaches to estimate LOD and LOQ of an HPLC method. Anal. Chem. 71 (14), 2672-2677.

Wolny, J.L., Egerton, T.A., Handy, S.M., Stutts, W.L., Smith, J.L., Whereat, E.B., Bachvaroff, T.R., Henrichs, D.W., Campbell, L., Deeds, J.R., 2020. Characterization of Dinophysis spp. (Dinophyceae, Dinophysiales) from the mid-Atlantic region of the United States (1). J. Phycol. 56 (2), 404-424. https://doi.org/10.1111/jpy.12966.

Yasumoto, T., Murata, M., Oshima, Y., Sano, M., 1985. Diarrhetic Shellfish Toxins. Tetrahedron 41 (6), 1019-1025.

Yasumoto, T., Oshima, Y., Sugawara, W., Fukuyo, Y., Oguri, H., Igarashi, T., Fujita, N., 1980. Identification of Dinophysis fortii as the causative organism of diarrhetic shellfish poisoning. Bull. Jpn. Soc. Sci. Fish. 46 (11), 1405-1411.

Zhang, H., Bhattacharya, D., Maranda, L., Lin, S.J., 2008. Mitochondrial cob and $\operatorname{cox} 1$ genes and editing of the corresponding mRNAs in Dinophysis acuminata from Narragansett Bay, with special reference to the phylogenetic position of the genus Dinophysis. Appl. Environ. Microbiol. 74 (5), 1546-1554.

Zingone, A., Larsen, A., Zingone, A.; Larsen, J. (Eds) Dinophysiales, in IOC-UNESCO taxonomic reference list of harmful micro algae. Available online at http://www.ma rinespecies.org/hab. Accessed on 2020-02-28.

Zingone, A., Montresor, M., Marino, D., 1998. Morphological variability of the potentially toxic dinoflagellate Dinophysis sacculus (Dinophyceae) and its taxonomic relationships with D. pavillardii and D. acuminata. Eur. J. Phycol. 33 (3), 259-273. 